ESID Working Paper No. 96

\title{
Is there a fiscal resource curse? \\ Resource rents, fiscal capacity and political institutions
}

Tania Masi, ${ }^{1}$ Antonio Savoia ${ }^{2}$ and Kunal Sen ${ }^{3}$

February, 2018

${ }^{1}$ University of Milano-Bicocca

Email correspondence: tania.masi@unimib.it

${ }^{2} \mathrm{GDI}$, The University of Manchester

Email correspondence: antonio.savoia@manchester.ac.uk

${ }^{3} \mathrm{GDI}$, The University of Manchester

Email correspondence: kunal.sen@manchester.ac.uk

ISBN: 978-1-908749-98-7 


\begin{abstract}
While several studies have focused on the effect of natural resources on economic development, less attention has been paid to their effects on other development outcomes. We contribute to this literature by studying the impact of resource rents on fiscal capacity, i.e., the ability of states to raise revenues from broad tax bases. We posit that natural resource rents reduce the incentives to invest in fiscal capacity. However, political institutions that limit the power of the executive, by reducing rulers' discretion over the use of resource revenues, may mitigate, neutralise or reverse such negative effect. We provide empirical support for this hypothesis using a recently constructed data set on non-resource taxes and panel methods for 98 developing countries covering the period 1981-2011. Moreover, we show that the effect of resource rents is likely to work mainly through institutions that make the tax system accountable and transparent to citizens. Our findings imply that it is possible to develop both fiscal capacity and the natural resources sector, without any tradeoff. Whether a fiscal resource curse exists or not is a question of what type of political institutions countries have adopted before they became resource-rich.
\end{abstract}

Keywords: state capacity, fiscal capacity, resource curse, institutions, economic development

JEL Codes: O4, P5, N4

Masi, T., Savoia, A. and Sen, K. (2018) Is there a fiscal resource curse? Resource rents, fiscal capacity and political institutions. ESID Working Paper No. 96. Manchester, UK: The University of Manchester. Available at www.effective-states.org

\footnotetext{
The background research for this paper was funded by the Effective States and Inclusive Development Research Centre (ESID), based at The University of Manchester, UK. This document is an output from a project funded by UK Aid from the UK government for the benefit of developing countries. However, the views expressed and information contained in it are not necessarily those of, or endorsed by the UK government, which can accept no responsibility for such views or information or for any reliance placed on them.
} 


\section{Introduction}

The effect of natural resource abundance on the economy has been a lively area of research for many years. ${ }^{1}$ Traditionally, most research has concentrated on long-term growth effects, initially finding a 'resource curse', and more recently arguing that the long-term effect of specialising in natural resources depends on the type of resources (e.g., Isham et al., 2005) and the quality of the institutional environment in the economy (e.g., Mehlum et al., 2006). ${ }^{2}$ As yet, less analysis has been devoted to other development outcomes. For example, underexplored areas include the effects on inequality (Carmignani, 2013, Goderis and Malone, 2011, Fum and Hodler, 2010), education (Ebeke et al., 2015, Stijns, 2006), health and living standards (Edwards, 2016, Pineda and Rodriguez, 2010, Caselli and Michaels, 2013). This paper contributes to the literature by looking at a further underexplored issue: the effects of natural resource income on state capacity and, in particular, fiscal capacity. ${ }^{3} \mathrm{We}$ provide a systematic econometric analysis of the effect of resource rents on tax systems, arguing that it appears to depend on the quality of political institutions.

Our hypothesis is that natural resource rents reduce the incentives to invest in fiscal capacity, but such an effect depends on whether political institutions limit the power of the executive and hence promote accountability and common interests. To test this hypothesis, we use panel methods on a sample of 91 developing countries from 1981 to 2011. Our fiscal capacity measure, the share of non-resource taxes on income, profits and capital gains on non-resource total taxes, is based on the intuition that collecting income taxes requires a more developed and competent administrative structure than raising other types of taxes (see Besley and Persson, 2014) and is constructed using the recent ICTD Government Revenues Dataset (Prichard et al., 2014), with improved coverage and the crucial distinction between resource and non-resource revenues. After extensive robustness checks, we find

\footnotetext{
${ }^{1}$ To explain its effects, research has referred to resource 'abundance' or 'rich', 'dependence', 'intensity', 'boom' or 'windfall' (see Norman, 2009; Stijns, 2006; Brunnschweiler and Bulte, 2008). The term 'dependence' usually refers to the structure of the economy (e.g., captured as resource exports/GDP). 'Intensity' refers to the rate at which one exploits natural resources. 'Boom' and 'windfall' pertain to shocks, either because new natural resources are discovered or because there is an increase in commodity prices. 'Abundance' or 'rich' concern the value of the natural resource endowments or the income they generate, measurable as subsoil wealth or resource rents, but they have also been used as terms encompassing all the above aspects. Here we use them in this latter sense.

${ }^{2}$ Many studies have addressed the counter-intuitive idea that countries rich in exploitable natural resources perform worse than those without. Much of the early literature argues the adverse effect of natural resource abundance on economic growth (e.g., Sachs and Warner, 1999, 2001; Rodriguez and Sachs, 1999; Gylfason, 2001). See van der Ploeg (2011) for a comprehensive survey of the hypotheses and evidence. Alongside the focus on growth, the literature has also shown that natural resources abundance leads to higher level of corruption (e.g., Caselli and Michaels, 2013), civil conflicts (e.g., Collier and Hoeffer, 2004), and less democracy (e.g., Ross, 2001). The negative effects of natural resources are, however, controversial. For example, Alexeev and Conrad (2009) claim that a large endowment of oil and mineral resources has a positive effect on long-term economic growth and does not negatively impact on the quality of institutions. Cotet and Tsui (2013) contradict the statistical association between the value of oil reserves and the onset of civil war, and Haber and Menaldo (2011) find that increasing resource dependence does not promote dictatorship over the long run. Bjorvatn and Naghavi (2011) argue that higher resource rents may promote political stability. Finally, Stijns (2006) denies the negative correlation between resource abundance and human capital. ${ }^{3}$ Following Besley and Persson (2011), we consider fiscal capacity as the ability of a fiscal system to raise revenues from a broad tax base.
} 
persuasive evidence that political institutions placing institutionalised constraints on the executive power may mitigate, neutralise or even reverse the negative effect of natural resources rents on fiscal infrastructures. Hence, a fiscal resource curse does not necessarily materialise. These results are complemented with further analysis to assess how the interaction between political institutions and resource rents impacts on specific aspects of fiscal capacity. Using a recent set of indicators provided by the Public Expenditure and Financial Accountability project (PEFA, 2006), we provide evidence suggesting that the effect works mainly through institutions that make the tax system accountable to, and transparent for citizens.

In addition to contributing to the literature on the resource curse, our paper adds to the research on the determinants of state capacity, an area that has so far seen relatively little empirical analysis (Savoia and Sen, 2015), despite now being considered strategically important for economic development (Besley and Persson, 2011). Indeed, the capacity to collect revenues is at the heart of state formation and is indispensable for the provision of public goods and investments in infrastructure (e.g., Osafo-Kwaako and Robinson, 2013; Charron et al., 2012), as stylised facts suggest that developing economies collect, on average, a significantly smaller share of taxes compared to advanced market economies (Besley and Persson, 2014). Hence, assessing whether a geographical feature shaping the structure of the economy, such as the presence of a significant natural resources sector, comes with the likely price of underdeveloped tax systems may have relevant policy tradeoffs. We find that this is not the case, if countries have suitable political institutions.

The paper is structured as follows: Section 2 reviews the literature and sets out our hypotheses; Section 3 describes the empirical strategy and data. In Section 4, we test our hypotheses and identify the specific channels through which natural resources affect the fiscal system. Section 5 concludes.

\section{Resource rents, fiscal capacity and political institutions}

There seems to be a consensus in the literature that increasing natural resources rents may be harmful to taxation, as governments tend to substitute tax revenues with resource revenues. Part of the literature has discussed this effect with respect to the short-term macroeconomic consequences for taxation, in terms of the amount and composition of tax revenues, as well as spending. James (2015) argues that a benevolent government decreases non-resource tax rates and increases spending and savings in response to higher resource revenues, providing US-state-level evidence: a \$1 increase in resource revenues results in a $\$ 0.25$ decrease in non-resource revenues, a $\$ 0.43$ increase in government spending and a $\$ 0.32$ increase in public savings. Morrison (2009) finds that an increase in non-tax revenues is associated with reduced taxation on elites in democracies, and more social spending in dictatorships. Focusing on the consequences for tax composition in resource-rich economies, Crivelli and Gupta (2014) find a large negative impact of resource revenues on the taxation of goods and services, and a more modest impact on corporate income tax and trade taxes. Looking at tax performance, Morrissey et al. (2016) find that a reliance on natural resources amplifies the negative effects of macroeconomic shocks (terms of trade, exchange rates and natural disasters) on total revenues. Interestingly, they also find 
that democracies tend to outperform non-democracies in revenue resilience to shocks in lower-income countries.

Recently, increasing attention has been paid to the long-term consequences, i.e., the effect of natural resources rents on tax system building. The political science literature had long characterised rentier states, whose main features are their weakness, lack of accountability of state institutions, and their dependence on revenues from natural resources (e.g., see Karl 2004). Building on this, the negative effect of resource rents on taxation can be explained by considering the incentives for investing in fiscal capacity, modelled as governments' investment choice under uncertainty (Besley and Persson, 2011). As incumbent governments can use resource revenues to provide public goods and services, and thereby increase political support, windfall revenues increase the likelihood that incumbents' choices are dominated by such redistributive interest, rather than a common interest, so reducing the incentive to invest in fiscal capacity. Knack (2009) provided initial cross-section evidence, partly consistent with this hypothesis. Jensen (2011) provides further evidence from a panel of 30 hydrocarbon-rich economies, finding that a 1 percent increase in hydrocarbon revenues causes a 1.5 percent decrease in non-resource tax effort, a proxy for fiscal capacity. An earlier panel study by Bornhorst et al. (2009), on a similar sample of countries and variables, finds a smaller effect: an additional percentage point of revenue from hydrocarbons reduces revenues from other domestic sources by 0.19 percentage points of GDP.

Although there is agreement on the negative effect of natural resources rents on fiscal capacity, the actual empirical evidence is fairly limited, often fraught with methodological challenges (e.g., measurement of fiscal capacity, endogeneity, sample size), and so in need of systematic investigation. Moreover, existing studies do not consider a crucial aspect at the heart of our analysis: the interplay between natural resources rents and the quality of institutions. A number of papers argue, and empirically demonstrate, that institutions can mitigate or even reverse the resource curse (e.g., Melhum et al., 2006; Brunnschweiler, 2008; Boschini et al., 2007; El Anshasy and Katsaiti, 2013; Bhattacharyya and Hodler, 2010, 2014; Ebeke et al., 2015; Omgba, 2015). ${ }^{4}$ Two explanations have been put forward to understand the role of institutions: the rent-seeking model (Tornell and Lane, 1999; Torvik, 2002; Melhum et al., 2006) and the patronage model (Robinson et al., 2006; Caselli and Cunningham, 2009). ${ }^{5}$ According to the former, the economic institutions governing the private sector are what matters. Resource rents change the preferences of private individuals so that they switch from productive to unproductive activities. Thus, natural resources hinder economic growth only if the quality of institutions that govern the profitability of productive enterprise is such that rent seeking is fostered. For example, Melhum et al. (2006) argue that the combination of resource abundance and grabber friendly institutions is detrimental for

\footnotetext{
${ }^{4}$ The literature interested in the effects on growth has proposed additional mitigating mechanisms. Andersen and Aslaksen (2008) argue that what matters in reducing negative effects on growth is the constitutional arrangement: presidential regimes and proportional electoral systems are more likely to be afflicted by the resource curse. The detrimental effect of natural resources on growth may also be reversed by high human capital endowments (Kurtz and Brooks, 2011), while public spending could mitigate civil conflicts related to oil wealth (Bodea et al., 2016).

${ }^{5}$ Caselli and Cunningham (2009) define the underlying mechanisms of these models as decentralised and centralised, respectively. Other mechanisms (soft budget constraint and wealth effect) are considered to be of secondary importance.
} 
economic development, while producer friendly institutions help countries take full advantage of their natural resource endowments. On the contrary, the patronage model focuses on the institutions governing the use of public sector resources. Resource rents increase the value of incumbency and provide ruling groups with more funds that can be used to retain power (e.g., to influence the outcome of elections), thereby increasing resource misallocation in the rest of the economy. However, institutions that promote accountability and state competence discourage the perverse political incentives that resource rents create.

Perverse effects from rent seeking and patronage are not mutually exclusive and can operate together. But is there an institutional environment where an economy can have both private sector and state institutions that avert rent-seeking and patronage mechanisms? This is where political institutions that place effective constraints on a ruler can play a major role. Such political systems promote contracting and property rights institutions, fostering productive activities, so that a large cross-section of society can take advantage of economic opportunities (Acemoglu, Johnson and Robinson, 2005). At the same time, limits on executive power promote a common interest environment, in which the ruling minority is unable to hand out favours to cronies or themselves (Besley and Persson, 2011). In this paper, focusing on this kind of political institution, we assess whether natural resource rents harm fiscal capacity and whether having a higher level of checks and balances on executive power can change this effect. Subject to checks and balances, a ruler has little discretion over the use of natural resource rents. Hence, he or she may be more likely to promote an effective independent civil service (rather than one based on patronage, which may

Figure 1. Relationship between non resource-tax and natural resources rents
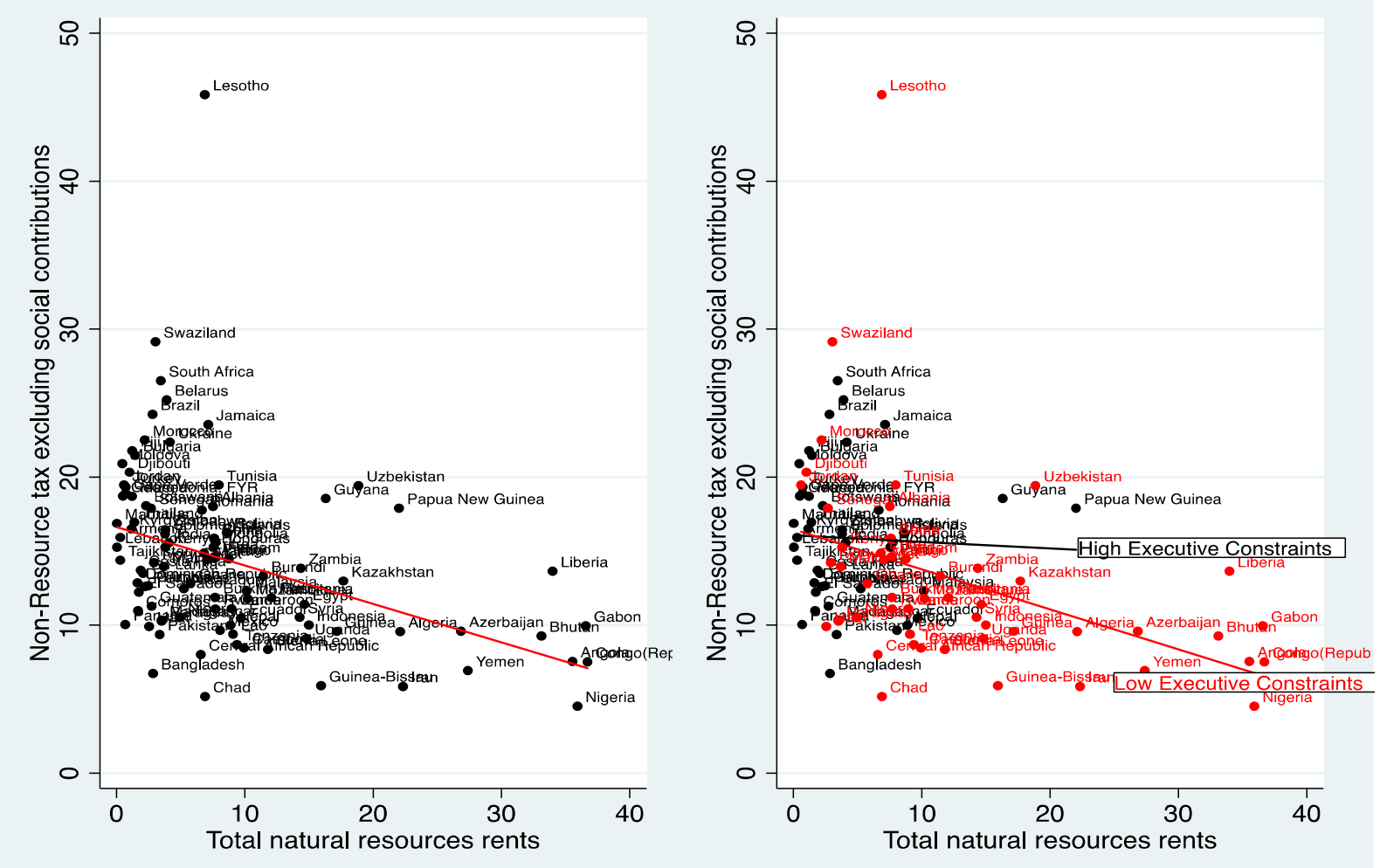
undermine the competence of the state bureaucracy) and so maintain or innovate fiscal infrastructures and the state's ability to raise tax revenues. Similarly, subject to clear limitations to his or her powers, a ruler is more likely to follow the rule of law, so that the judicial system may counter rent-seeking more effectively, and have a more transparent policy process, so reducing waste and corruption. Figure 1 suggests that a fiscal resource curse does exist: countries with a high level of total natural resources rents collect a low level of taxes as a percentage of GDP. However, splitting the sample into countries with political institutions placing high and low levels of constraints on the executive power (right-hand scatter plot) shows that the effect of resource rents on taxation can be heterogeneous. ${ }^{6}$

Let us reformulate our argument on the role of natural resource rents in developing fiscal capacity and their interplay with political institutions via two testable hypotheses:

i. Resource rents reduce the incentives to invest in fiscal capacity, so resourcerich countries have less developed tax systems.

ii. Political institutions placing limits on the executive powers foster productive activities and promote common interests, so raising the incentives for investing in fiscal capacity. The negative effect of natural resources rents on fiscal infrastructure is therefore mitigated, neutralised or even reversed in countries with a higher level of executive constraints.

The following sections investigate the above hypotheses, using different measures of fiscal capacity.

\section{Empirical strategy and data}

The previous section suggests that there may be a non-linear relationship between resource rents and fiscal capacity, depending on the type of political institutions. In principle, there are two possible approaches to estimate this relationship.

The former estimates the relationship under investigation using cross-country data in levels, since the types of mechanism we seek to document look at the structural conditions under which countries develop capable states, and are, therefore, long-term in nature. In this case, regressions based on cross-section averages, as shown in Figures 1 and $1 \mathrm{~A}$, are suitable. However, there are at least two problems with this approach. The first is the vulnerability to omitted variable bias, as there may be several hard-to-capture factors correlated with both the volume of resource rents and state capacity. The second is that shaping the structure of the economy, including its degree of reliance on natural resources, is a process driven by a variety of social forces, including state institutions. Hence, the estimated effect of natural resource reliance could be affected by reverse causality and be subject to bias.

\footnotetext{
${ }^{6}$ Taxes are defined as the non-resource component of total tax revenues excluding social contributions, from ICTD (2015), and are averaged over 2000-2011. Total natural resources rents are averaged between 1970 and 1999 and are from World Bank (2016). To divide the sample, we consider the median value of executive constraints from Polity IV (Marshall et al., 2014). Variables and sources are described in Table $1 \mathrm{~A}$ in the Appendix. The apparently heterogeneous effect of natural resource rents is confirmed even when a possible outlier such as Lesotho is excluded from the sample (Figure 1A in the Appendix). Note also that resource rents do not include diamond revenues amongst their minerals, and hence this obscures interesting comparisons such as Botswana vs. Sierra Leone.
} 
The second approach relies on assessing whether the type of relationship documented in Figures 1 and $1 \mathrm{~A}$ disappears when looking at the effect of changes in resource rents on fiscal capacity. If it does not, we are probably capturing a causal effect. This approach involves the use of panel methods, conditional at the initial level on political institutions. In particular, looking at the effect of changes in resource income on fiscal capacity eliminates confounding time-invariant country-specific factors. That is, fixed effects can be added to take care of country-specific factors affecting both resource rents and fiscal capacity, while time effects can be added to control for global trends.

We prefer the panel approach, but we also present cross-section estimates (as we attempt to capture the effects of resource rents on specific institutional aspects of the tax systems). This is coupled with the choice of a resource income variable allowing clean identification of its effect. We use resource rent data, as a share of national income, provided by the World Bank. ${ }^{7}$ Such variables are based on commodity prices. Assuming that both the identity of a country's commodities and world prices are largely exogenous to state institutions, this measure avoids identification problems related to the estimation of the effects of natural resources (this approach was first proposed by Caselli and Tesei, 2016). This assumption can be tested, albeit indirectly. We investigate whether it holds by excluding from the sample large commodity-producing countries able to influence world prices.

We estimate:

$$
\mathrm{FC}_{i \mathrm{t}}=b_{0}+b_{1} \mathrm{RR}_{\mathrm{it}-4-\mathrm{bar}}+b_{2} \mathrm{EC}_{\mathrm{it}-4}+b_{3} \mathrm{RR}_{\mathrm{it}-4-\mathrm{bar}}{ }^{*} \mathrm{EC}_{\mathrm{it}-4}+\boldsymbol{b} \mathbf{X}_{\mathrm{it}}+\mu_{\mathrm{i}}+\lambda_{\mathrm{t}}+u_{i t}
$$

$\mathrm{FC}_{\text {it }}$ is fiscal capacity for country $i$ at time $t$. Capturing this concept is particularly challenging. ${ }^{8}$ The literature identifies two approaches. The first one, which is near ideal, as it is closer to the concept one wants to capture, is to have a direct measure of the institutions that are part of the tax system, but such measures are scarce, cover few countries (when available), and are not immune from methodological challenges themselves. ${ }^{9}$ The second one is to resort to outcome-based proxies, such as tax effort ratios. Such measures may well reflect political preferences of a polity towards the size of the public sector and the scope for redistribution (Lieberman, 2002), but they have the major advantage of being available for a large number of countries over time. We use both types of fiscal capacity measures. In cross-section results, we use the first type. In panel regressions, instead, the second one: our measure of

\footnotetext{
${ }^{7}$ Resource rent estimation is based on sources and methods fully described by the World Bank (2011), i.e., on the difference between the price of a commodity and the average cost of producing it, estimating the world price of units of specific commodities and subtracting estimates of average unit costs of extraction or harvesting costs (including a normal return on capital). The unit rents are then multiplied by the quantities that countries extract or harvest to determine the rents for each commodity as a share of gross domestic product (GDP). Such measures are based on estimates and therefore are subject to measurement error. However, as long as the noise approximates classic errors in variables case, this is a source of attenuation bias. Therefore, it stacks the odds against our results implying that estimates of the effects of natural resource rents may be conservative.

${ }^{8}$ The perennial challenge of measuring state capacity is to avoid conflating state capacity (which is about institutions) with state performance (which is about outcomes). See the discussion in Centeno et al. (2017).

${ }^{9}$ The practice of measurement involves making choices subject to significant trade-offs (e.g., objective versus subjective measurement, or de jure versus de facto). On this, see Savoia and Sen (2015).
} 
fiscal capacity is given by the ratio between non-resource taxes on income, profits, and capital gains and total non-resource tax revenues. Contrary to previous proxies of fiscal capacity, often based on the amount of total taxes as a percentage of GDP, ours is more likely to separate the capacity to raise taxes from governments' policy choices. Indeed, collecting income taxes requires major investments in fiscal infrastructures compared to other types of taxes (Besley and Persson, 2011: 41-42). Data was taken from the recent Government Revenues Dataset (GRD) (see Prichard et al., 2014). This dataset combines data from several international databases, with marked improvements in data coverage. Crucially, it also allows us to distinguish the natural resources component of tax revenues from the non-resource one, so improving the accuracy of measurement. ${ }^{10}$

$\mathrm{RR}_{\mathrm{t}-4 \text {-bar }}$ is the resource rent, as described above, averaged over $t-4$ to $t-1$ (with a nonoverlapping structure), allowing for possible lags in the reaction of fiscal authorities to events in the natural resources sector and in the political system. ${ }^{11} \mathrm{EC}_{\mathrm{t}-4}$ captures the quality of political institutions at $t-4$, the beginning of each episode. In line with our hypothesis, it is measured by the Executive Constraints variable (xconst), provided by the Polity IV dataset (Marshall et al., 2014) and capturing the extent of constitutional limits on the exercise of arbitrary power by the executive. $\mathrm{RR}_{\mathrm{it}-4 \text {-bar }}{ }^{*} \mathrm{EC}_{\mathrm{it}-4}$ is the interaction between natural resources and institutional quality.

$\mathrm{X}_{\mathrm{it}}$ is a set of time-varying controls (also averaged over $t-4$ to $t-1$, with a non-overlapping structure). Some of them are standard variables from the literature on the origins of state capacity, including political stability, population density, external and internal conflict, and aid. According to Besley and Persson (2011), if political instability is higher, that is, an incumbent faces a higher probability of replacement, the incentive to invest in fiscal capacity may decrease, as such investments may enable more redistribution to rival groups. We control for this variable using the sum of Openness of executive recruitment (xropen) and Competitiveness of executive recruitment (xrcomp) from the Polity IV dataset (Marshall et al., 2014). Population density should be positively correlated with state capacity, assuming that it is less challenging to develop a fiscal apparatus in states where the population is concentrated in urban areas (Herbst, 2000). We use the number of people per square kilometres of land, as calculated by the World Bank (2016). External conflicts increase the demand for public services such as defence and thereby increase the incentive to invest in state capacity. On the contrary, civil wars, promoting redistributive interests, hinder the construction of an efficient fiscal apparatus (Besley and Persson, 2011). To capture these effects, we use the hostility level of interstate disputes (Palmer et al., 2015) and the intensity level of internal and internationalised internal armed conflict (UCDP/PRIO, 2016),

\footnotetext{
${ }^{10}$ We use the merged version of the GRD dataset in order not to underestimate fiscal capacity in countries with a federal system.

${ }^{11}$ This approach appears to be standard in the resource curse literature (e.g., Caselli and Tesei, 2016, and Bhattacharyya and Hodler, 2010), as well as broader political economy literature investigating institutional factors (e.g., Klomp and de Haan, 2016). Presumably, empirical analyses using a panel with 'high frequency' data (e.g., yearly) would fail to properly capture structural characteristics.
} 
Table 1. Summary statistics

\begin{tabular}{|c|c|c|c|c|c|c|c|c|c|}
\hline \multirow{2}{*}{ Panel (a) } & \multirow{2}{*}{ Observations } & \multirow{2}{*}{ Mean } & \multicolumn{4}{|c|}{ Std. Dev } & \multirow{2}{*}{\multicolumn{2}{|c|}{ Minimum }} & \multirow[t]{2}{*}{ Maximum } \\
\hline & & & \multicolumn{2}{|r|}{ overall } & between & within & & & \\
\hline Fiscal capacity & 350 & 29.858 & \multicolumn{2}{|r|}{11.827} & 10.286 & 5.947 & \multicolumn{2}{|c|}{7.052} & 68.692 \\
\hline Executive constraints & 350 & 4.446 & \multicolumn{2}{|r|}{2.003} & 1.711 & 1.200 & \multicolumn{2}{|c|}{1} & 7 \\
\hline Total natural resources rents & 350 & 8.497 & \multicolumn{2}{|c|}{10.954} & 12.878 & 3.212 & \multicolumn{2}{|c|}{0.003} & 70.624 \\
\hline Forest rents & 350 & 3.449 & \multicolumn{2}{|r|}{5.685} & 5.893 & 2.196 & \multicolumn{2}{|c|}{0} & 41.770 \\
\hline Oil rents & 350 & 3.028 & \multicolumn{2}{|r|}{8.242} & 10.372 & 1.597 & \multicolumn{2}{|c|}{0} & 50.107 \\
\hline Gas rents & 350 & 0.895 & \multicolumn{2}{|r|}{4.105} & 5.192 & 1.275 & \multicolumn{2}{|c|}{0} & 55.528 \\
\hline Mineral rents & 350 & 1.045 & \multicolumn{2}{|r|}{2.863} & 2.718 & 1.432 & \multicolumn{2}{|c|}{0} & 20.618 \\
\hline Political stability & 350 & 3.093 & \multicolumn{2}{|r|}{1.187} & 1.007 & 0.485 & \multicolumn{2}{|c|}{2} & 7 \\
\hline External Debt & 350 & 71.510 & \multicolumn{2}{|c|}{87.168} & 78.008 & 53.229 & \multicolumn{2}{|c|}{2.725} & 759.970 \\
\hline Trade & 350 & 75.696 & \multicolumn{2}{|r|}{38.127} & 35.851 & 14.345 & \multicolumn{2}{|c|}{13.037} & 253.047 \\
\hline Net ODA and aid per capita & 350 & 71.208 & \multicolumn{2}{|r|}{84.082} & 76.157 & 34.113 & \multicolumn{2}{|c|}{-3.785} & 620.926 \\
\hline Population density & 350 & 98.265 & \multicolumn{2}{|c|}{142.726} & 139.294 & 18.085 & \multicolumn{2}{|c|}{1.462} & 1145.363 \\
\hline External conflict & 350 & 0.955 & & 1.326 & 1.252 & 0.704 & & & 5 \\
\hline Civil war & 350 & 0.238 & & 0.492 & 0.335 & 0.340 & & & 2 \\
\hline & & $11-1990$ & & & $1991-2000$ & & & $001-201$ & \\
\hline Panel (b) & & d. Dev & & & Std. Dev & & & Std. Dev & \\
\hline & overall & between & within & overall & between & within & overall & between & within \\
\hline Fiscal capacity & 12.348 & 11.502 & 3.654 & 12.106 & 11.342 & 4.415 & 11.642 & 10.982 & 4.077 \\
\hline Executive constraints & 2.050 & 1.960 & 0.762 & 1.992 & 1.776 & 1.017 & 1.829 & 1.736 & 0.672 \\
\hline Total natural resources rents & 12.983 & 11.753 & 3.487 & 7.742 & 9.040 & 1.758 & 12.920 & 14.113 & 3.172 \\
\hline Forest rents & 8.665 & 7.330 & 2.480 & 5.251 & 4.837 & 1.170 & 5.287 & 6.003 & 1.201 \\
\hline Oil rents & 11.167 & 9.922 & 2.398 & 5.631 & 7.999 & 1.078 & 8.418 & 10.644 & 1.161 \\
\hline Gas rents & 0.648 & 0.731 & 0.095 & 1.212 & 1.351 & 0.278 & 6.553 & 6.266 & 1.583 \\
\hline Mineral rents & 2.962 & 4.608 & 0.358 & 2.625 & 2.306 & 0.788 & 2.982 & 2.663 & 1.483 \\
\hline
\end{tabular}

respectively. Development assistance has often been compared to natural resources in terms of its possible patronage effect (e.g., Morrison, 2010). We use data from the World Bank (2016) to assess whether aid dependence decreases investments in fiscal capacity. Finally, given the nature of our proxy for fiscal capacity, we also add controls that are macroeconomic in nature, as suggested in empirical studies on tax effort (e.g., Crivelli and Gupta, 2014): the level of external debt and the sum of exports and imports of goods and services measured as a share of gross domestic product. Table 1A (in the Appendix) describes variables and sources, and Table $2 \mathrm{~A}$ describes the sample.

All regressions include country and year dummies ( $\mu_{\mathrm{i}}$ and $\lambda_{\mathrm{t}}$, respectively). Standard errors 
are clustered at the country level to allow for unknown forms of heteroskedasticity and serial correlation. We study a sample of 98 developing countries from 1981 to 2011. The descriptive statistics presented in Table 1 show that our key variables vary both across countries and over time. Breaking the period down into decades shows that such a pattern of variation is not driven by any particular sub-period (Table 1, panel b).

\section{Results}

This section presents the results, in four steps. We first consider the total amount of resource rents. Then, we decompose it to look at how different natural resources affect fiscal capacity. A series of robustness checks follows. Finally, we present further results, based on crosssection estimates, unpacking fiscal capacity to identify which institutions within the tax system are affected.

\subsection{The effect of natural resources rents on fiscal capacity}

Table 2 presents our baseline results. Columns 1-3, where the variable of interest enters in linear form, show a negative but not significant effect of total natural resource rents on fiscal capacity. However, once we consider the possibility of a non-linear relationship between resource rents and fiscal capacity, the coefficient of total natural resource rents is significant and so is its interaction term with our measure of political institutions. Column 4 shows that on average fiscal capacity tends to be lower when countries experience an increase in resource rents. However, the interaction term appears significantly positive, suggesting that the negative effect of resource rents diminishes when the level of executive constraints increases. This result holds when the set of controls is included (Column 5). External debt, population density and civil war are significant and have the expected signs: fiscal capacity is higher for less sparsely populated states, whereas external debt and civil war decrease the investments in tax infrastructures.

Column 1 in Table 4 shows the marginal effects of total natural resource rents at different levels of constraints on the executive. The results confirm our hypotheses: resource rents negatively affect fiscal capacity when the level of executive constraints is very low, but they can even be a blessing for countries where the executive power is subject to effective checks and balances. For countries, such as Congo, Gabon and Uzbekistan, where constitutional restrictions on executive action are weak (xconst=1 for significant periods), a one percentage point increase in total natural resource rents would reduce the ability to raise direct taxes, our proxy for fiscal capacity, by approximately 0.41 percentage points. On the other hand, in countries with the highest level of executive constraints (e.g., Albania and Costa Rica), the same increase in resource rents would improve fiscal capacity by 0.37 percent. ${ }^{12}$

\footnotetext{
${ }^{12}$ For the sake of thoroughness, we have also considered the partial effect of executive constraints at different levels of resource rents. For instance, natural resource rents in developing economies can stifle democratic governance and political institutions via rent-seeking activities by influential private actors or through patronage by the local elite. Hence, an alternative interpretation to our interaction term is that developing economies with less natural resource income may be less prone to such effects. To test this hypothesis, we estimated the magnitude and significance of the partial effect of executive constraints calculated at different levels of resource rents. Such estimates, available on request, show that the effect of executive constraints can decrease in magnitude and even change sign in environments with higher resource rents. However, there is no evidence that such effects are significant at conventional levels.
} 
Considering that the (within) standard deviation in resource rents is above three percentage points, such effects also appear to be economically significant.

Table 2. Baseline results: fiscal capacity and total natural resources rents

\begin{tabular}{|c|c|c|c|c|c|}
\hline & (1) & (2) & (3) & (4) & (5) \\
\hline \multirow[t]{2}{*}{ Total natural resources rents } & -0.127 & -0.122 & -0.0759 & $-0.591 * * *$ & $-0.544^{* *}$ \\
\hline & $(0.157)$ & $(0.158)$ & $(0.194)$ & $(0.223)$ & $(0.254)$ \\
\hline \multirow[t]{2}{*}{ Executive constraints } & & 0.238 & 0.360 & -0.612 & -0.522 \\
\hline & & $(0.354)$ & $(0.458)$ & $(0.432)$ & $(0.493)$ \\
\hline \multirow[t]{2}{*}{ Tot. nat resource. rents*Exec. constraints } & & & & $0.126^{* * *}$ & $0.131 * * *$ \\
\hline & & & & $(0.0315)$ & $(0.0368)$ \\
\hline \multirow[t]{2}{*}{ Political Stability } & & & 0.651 & & 0.461 \\
\hline & & & $(0.950)$ & & $(0.870)$ \\
\hline \multirow[t]{2}{*}{ External Debt } & & & $-0.0188 * *$ & & $-0.0165^{* * *}$ \\
\hline & & & $(0.00747)$ & & $(0.00578)$ \\
\hline \multirow[t]{2}{*}{ Trade } & & & 0.0211 & & 0.00306 \\
\hline & & & $(0.0302)$ & & $(0.0296)$ \\
\hline \multirow[t]{2}{*}{ Net ODA and aid per capita } & & & -0.00353 & & -0.0114 \\
\hline & & & $(0.0139)$ & & $(0.0138)$ \\
\hline \multirow[t]{2}{*}{ Population density } & & & $0.0521 *$ & & $0.0588 * *$ \\
\hline & & & $(0.0269)$ & & $(0.0265)$ \\
\hline \multirow[t]{2}{*}{ External conflict } & & & 0.502 & & 0.482 \\
\hline & & & $(0.720)$ & & $(0.679)$ \\
\hline \multirow[t]{2}{*}{ Civil war } & & & $-2.638 * *$ & & $-2.947 * *$ \\
\hline & & & (1.317) & & (1.303) \\
\hline \multirow[t]{2}{*}{ Constant } & $31.50^{* * *}$ & $30.65^{* * *}$ & $22.99 * * *$ & $35.43^{* * *}$ & $29.91 * * *$ \\
\hline & $(2.480)$ & (2.620) & (5.530) & (3.219) & (5.794) \\
\hline Observations & 350 & 350 & 350 & 350 & 350 \\
\hline Number of countries & 91 & 91 & 91 & 91 & 91 \\
\hline Adjusted R-squared & 0.094 & 0.093 & 0.148 & 0.144 & 0.200 \\
\hline Year FE & YES & YES & YES & YES & YES \\
\hline Country FE & YES & YES & YES & YES & YES \\
\hline Joint(p) & & & & 0.000615 & 0.00217 \\
\hline
\end{tabular}

Notes: The dependent variable is non-resource income tax as a percentage of non-resource total tax revenue. Robust standard errors in parentheses. ${ }^{* * *} p<0.01,{ }^{* *} p<0.05,{ }^{*} p<0.1$.

Next, we assess the effect of specific natural resources (Tables 3 and 4). Some studies suggest that the resource curse may by driven by specific types of natural resource 
Is there a fiscal resource curse? Resource rents, fiscal capacity and political institutions.

Table 3. Fiscal capacity and different natural resources rents

\begin{tabular}{|c|c|c|c|c|c|}
\hline & $\begin{array}{c}\text { (1) } \\
\text { All Rents }\end{array}$ & $\begin{array}{c}\text { (2) } \\
\text { no forest }\end{array}$ & $\begin{array}{c}\text { (3) } \\
\text { no oil }\end{array}$ & $\begin{array}{c}\text { (4) } \\
\text { no gas }\end{array}$ & $\begin{array}{c}(5) \\
\text { no mineral }\end{array}$ \\
\hline Forest rents & $\begin{array}{c}-1.108^{* * *} \\
(0.177)\end{array}$ & & $\begin{array}{c}-1.046^{* * *} \\
(0.165)\end{array}$ & $\begin{array}{c}-1.107 * * * \\
(0.184)\end{array}$ & $\begin{array}{c}-0.997 * * * \\
(0.179)\end{array}$ \\
\hline Forest rents*Executive constraints & $\begin{array}{c}0.169 * * * \\
(0.0548)\end{array}$ & & $\begin{array}{c}0.158^{* * *} \\
(0.0539)\end{array}$ & $\begin{array}{c}0.164 * * * \\
(0.0553)\end{array}$ & $\begin{array}{c}0.182 * * * \\
(0.0522)\end{array}$ \\
\hline Oil rents & $\begin{array}{c}-0.289 \\
(0.364)\end{array}$ & $\begin{array}{c}-0.193 \\
(0.357)\end{array}$ & & $\begin{array}{l}-0.211 \\
(0.367)\end{array}$ & $\begin{array}{l}-0.267 \\
(0.365)\end{array}$ \\
\hline Gas rents & $\begin{array}{c}0.410 \\
(0.464)\end{array}$ & $\begin{array}{c}0.451 \\
(0.428)\end{array}$ & $\begin{array}{c}0.317 \\
(0.505)\end{array}$ & & $\begin{array}{c}0.555 \\
(0.402)\end{array}$ \\
\hline Gas rents*Executive constraints & $\begin{array}{c}0.0354 \\
(0.0864)\end{array}$ & $\begin{array}{c}0.0238 \\
(0.0776)\end{array}$ & $\begin{array}{l}0.0938 \\
(0.101)\end{array}$ & & $\begin{array}{c}0.0169 \\
(0.0745)\end{array}$ \\
\hline Mineral rents & $\begin{array}{c}-1.244 * * \\
(0.588)\end{array}$ & $\begin{array}{l}-0.756 \\
(0.555)\end{array}$ & $\begin{array}{l}-1.146^{*} \\
(0.586)\end{array}$ & $\begin{array}{c}-1.382^{* *} \\
(0.581)\end{array}$ & \\
\hline External debt & $\begin{array}{c}-0.0133^{* * *} \\
(0.00487)\end{array}$ & $\begin{array}{c}-0.0223^{* * *} \\
(0.00791)\end{array}$ & $\begin{array}{c}-0.0138 * * * \\
(0.00505)\end{array}$ & $\begin{array}{c}-0.0138 * * * \\
(0.00509)\end{array}$ & $\begin{array}{c}-0.0118^{* *} \\
(0.00534)\end{array}$ \\
\hline Trade & $\begin{array}{c}-7.97 \mathrm{e}-05 \\
(0.0316)\end{array}$ & $\begin{array}{c}0.0132 \\
(0.0295)\end{array}$ & $\begin{array}{l}-0.00299 \\
(0.0316)\end{array}$ & $\begin{array}{l}0.00237 \\
(0.0321)\end{array}$ & $\begin{array}{l}-0.00149 \\
(0.0313)\end{array}$ \\
\hline Net ODA and aid per capita & $\begin{array}{c}-0.0113 \\
(0.0146)\end{array}$ & $\begin{array}{r}-0.00355 \\
(0.0143)\end{array}$ & $\begin{array}{c}-0.0118 \\
(0.0152)\end{array}$ & $\begin{array}{c}-0.0111 \\
(0.0145)\end{array}$ & $\begin{array}{c}-0.0112 \\
(0.0149)\end{array}$ \\
\hline Population density & $\begin{array}{c}0.0569 * * \\
(0.0250)\end{array}$ & $\begin{array}{c}0.0578 * * \\
(0.0271)\end{array}$ & $\begin{array}{c}0.0549 * * \\
(0.0247)\end{array}$ & $\begin{array}{c}0.0564 * * \\
(0.0246)\end{array}$ & $\begin{array}{c}0.0585 * * \\
(0.0256)\end{array}$ \\
\hline External conflict & $\begin{array}{c}0.299 \\
(0.674)\end{array}$ & $\begin{array}{c}0.366 \\
(0.699)\end{array}$ & $\begin{array}{c}0.247 \\
(0.702)\end{array}$ & $\begin{array}{c}0.388 \\
(0.664)\end{array}$ & $\begin{array}{c}0.345 \\
(0.696)\end{array}$ \\
\hline Civil war & $\begin{array}{c}-3.070^{* *} \\
(1.304)\end{array}$ & $\begin{array}{c}-2.736^{* *} \\
(1.374)\end{array}$ & $\begin{array}{c}-2.919 * * \\
(1.303)\end{array}$ & $\begin{array}{c}-3.045^{* *} \\
(1.296)\end{array}$ & $\begin{array}{c}-3.018^{* *} \\
(1.305)\end{array}$ \\
\hline Constant & $\begin{array}{c}32.24 * * * \\
(5.862)\end{array}$ & $\begin{array}{c}25.69 * * * \\
(5.712)\end{array}$ & $\begin{array}{c}30.10 * * * \\
(5.586)\end{array}$ & $\begin{array}{c}32.39 * * * \\
(5.990)\end{array}$ & $\begin{array}{c}30.76 * * * \\
(6.023)\end{array}$ \\
\hline
\end{tabular}

Notes: The dependent variable is non-resource income tax as a percentage of non-resource total tax revenue. Robust standard errors in parentheses.

${ }^{* * *} p<0.01,{ }^{* *} p<0.05,{ }^{*} p<0.1$ 
Table 4. Fiscal capacity and different natural resources rents - sum of rents

\begin{tabular}{|c|c|c|c|c|}
\hline & $\begin{array}{c}(1) \\
\text { no forest rents }\end{array}$ & $\begin{array}{c}(2) \\
\text { no oil rents } \\
\end{array}$ & $\begin{array}{c}\text { (3) } \\
\text { no gas rents }\end{array}$ & $\begin{array}{c}(4) \\
\text { no mineral rents }\end{array}$ \\
\hline Executive constraints & $\begin{array}{l}0.0471 \\
(0.456)\end{array}$ & $\begin{array}{l}-0.359 \\
(0.464)\end{array}$ & $\begin{array}{l}-0.516 \\
(0.516)\end{array}$ & $\begin{array}{l}-0.454 \\
(0.520)\end{array}$ \\
\hline Total resources rents without forest rents & $\begin{array}{l}-0.230 \\
(0.154)\end{array}$ & & & \\
\hline Interaction without forest & $\begin{array}{c}0.0905^{* * *} \\
(0.0275)\end{array}$ & & & \\
\hline Total resources rents without oil rents & & $\begin{array}{c}-0.761^{* * *} \\
(0.220)\end{array}$ & & \\
\hline Interaction without oil rents & & $\begin{array}{c}0.157 * * * \\
(0.0468)\end{array}$ & & \\
\hline Total resources rents without gas rents & & & $\begin{array}{c}-0.732 * * * \\
(0.247)\end{array}$ & \\
\hline Interaction without gas rents & & & $\begin{array}{l}0.142 * * * \\
(0.0399)\end{array}$ & \\
\hline Total resources rents without mineral rents & & & & $\begin{array}{l}-0.433^{*} \\
(0.242)\end{array}$ \\
\hline Interaction without mineral rents & & & & $\begin{array}{l}0.131^{* * *} \\
(0.0364)\end{array}$ \\
\hline Political stability & $\begin{array}{c}0.167 \\
(0.907)\end{array}$ & $\begin{array}{c}0.525 \\
(0.875)\end{array}$ & $\begin{array}{c}0.620 \\
(0.865)\end{array}$ & $\begin{array}{c}0.259 \\
(0.883)\end{array}$ \\
\hline External debt & $\begin{array}{c}-0.0198^{* * * *} \\
(0.00629)\end{array}$ & $\begin{array}{c}-0.0160 * * * \\
(0.00544)\end{array}$ & $\begin{array}{l}-0.0142^{* *} \\
(0.00550)\end{array}$ & $\begin{array}{c}-0.0178 * * * \\
(0.00664)\end{array}$ \\
\hline Trade & $\begin{array}{c}0.0198 \\
(0.0286)\end{array}$ & $\begin{array}{l}-0.00527 \\
(0.0325)\end{array}$ & $\begin{array}{l}0.00927 \\
(0.0300)\end{array}$ & $\begin{array}{l}0.00212 \\
(0.0291)\end{array}$ \\
\hline Net ODA and aid per capita & $\begin{array}{l}-0.00244 \\
(0.0136)\end{array}$ & $\begin{array}{l}-0.0136 \\
(0.0143)\end{array}$ & $\begin{array}{l}-0.0126 \\
(0.0136)\end{array}$ & $\begin{array}{l}-0.0122 \\
(0.0146)\end{array}$ \\
\hline Population density & $\begin{array}{l}0.0623^{* *} \\
(0.0267)\end{array}$ & $\begin{array}{l}0.0565 * * \\
(0.0259)\end{array}$ & $\begin{array}{c}0.0545 * * \\
(0.0257)\end{array}$ & $\begin{array}{c}0.0601^{* *} \\
(0.0267)\end{array}$ \\
\hline External conflict & $\begin{array}{c}0.541 \\
(0.710)\end{array}$ & $\begin{array}{c}0.433 \\
(0.706)\end{array}$ & $\begin{array}{c}0.480 \\
(0.666)\end{array}$ & $\begin{array}{c}0.431 \\
(0.691)\end{array}$ \\
\hline Civil war & $\begin{array}{c}-2.906^{* *} \\
(1.384)\end{array}$ & $\begin{array}{c}-2.809 * * \\
(1.305)\end{array}$ & $\begin{array}{c}-3.019 * * \\
(1.270)\end{array}$ & $\begin{array}{c}-2.783^{* *} \\
(1.291)\end{array}$ \\
\hline Constant & $\begin{array}{c}24.84 * * * \\
(5.645)\end{array}$ & $\begin{array}{c}29.11^{* * * *} \\
(5.587)\end{array}$ & $\begin{array}{c}30.65^{* * * *} \\
(5.932)\end{array}$ & $\begin{array}{c}29.60 * * * \\
(5.866)\end{array}$ \\
\hline Observations & 355 & 350 & 350 & 350 \\
\hline R-squared & 0.204 & 0.227 & 0.245 & 0.233 \\
\hline Number of country & 92 & 91 & 91 & 91 \\
\hline Year FE & YES & YES & YES & YES \\
\hline Country FE & YES & YES & YES & YES \\
\hline Joint(p) & 0.00607 & 0.00204 & 0.00180 & 0.00155 \\
\hline
\end{tabular}

Notes: The dependent variable is non-resource income tax as a percentage of non-resource total tax revenue. Robust standard errors in parentheses. ${ }^{* * *} p<0.01,{ }^{* *} p<0.05,{ }^{*} p<0.1$.

endowments (Isham et al., 2005, Boschini et al., 2007), hence we consider individual components of total natural resource rents: forest, oil, gas, and mineral rents. ${ }^{13}$

Disaggregating the effects, Table 3 indicates that none of the four types of resource rents is the sole force driving the heterogeneous effect on fiscal capacity. Indeed, linear restriction tests always reject the null that the effects of different resources are jointly equal to zero. We also test the linear restriction that the coefficient of each type of resource and its interaction

\footnotetext{
${ }^{13}$ It would be also interesting to consider, in terms of impact on fiscal capacity, the distinction between 'lootable' and 'non-lootable' natural resources, for example, as proposed by Vahabi (2016). Whether the state fiscal capacity is sensitive to the specific appropriablity profile of natural resources is left for future research. Incidentally, the World Bank also provides data for coal rents, but they are ignored because of lack of variation (very few observations are different from zero).
} 
term are jointly equal to zero, always rejecting it. ${ }^{14}$ As a final check, in Table 4 , we repeat the regression in the last column of Table 2 excluding, in turn, each type of resource from total rents. The interaction effect stays unchanged in all cases. All this suggests that the interaction effect is at work for each specific resource and that no specific type of resource rents dominates the results. The general message remains that natural resources may be a curse or a blessing, depending on the level of executive constraints.

Table 5. Marginal effects of resource rents at different levels of executive constraints

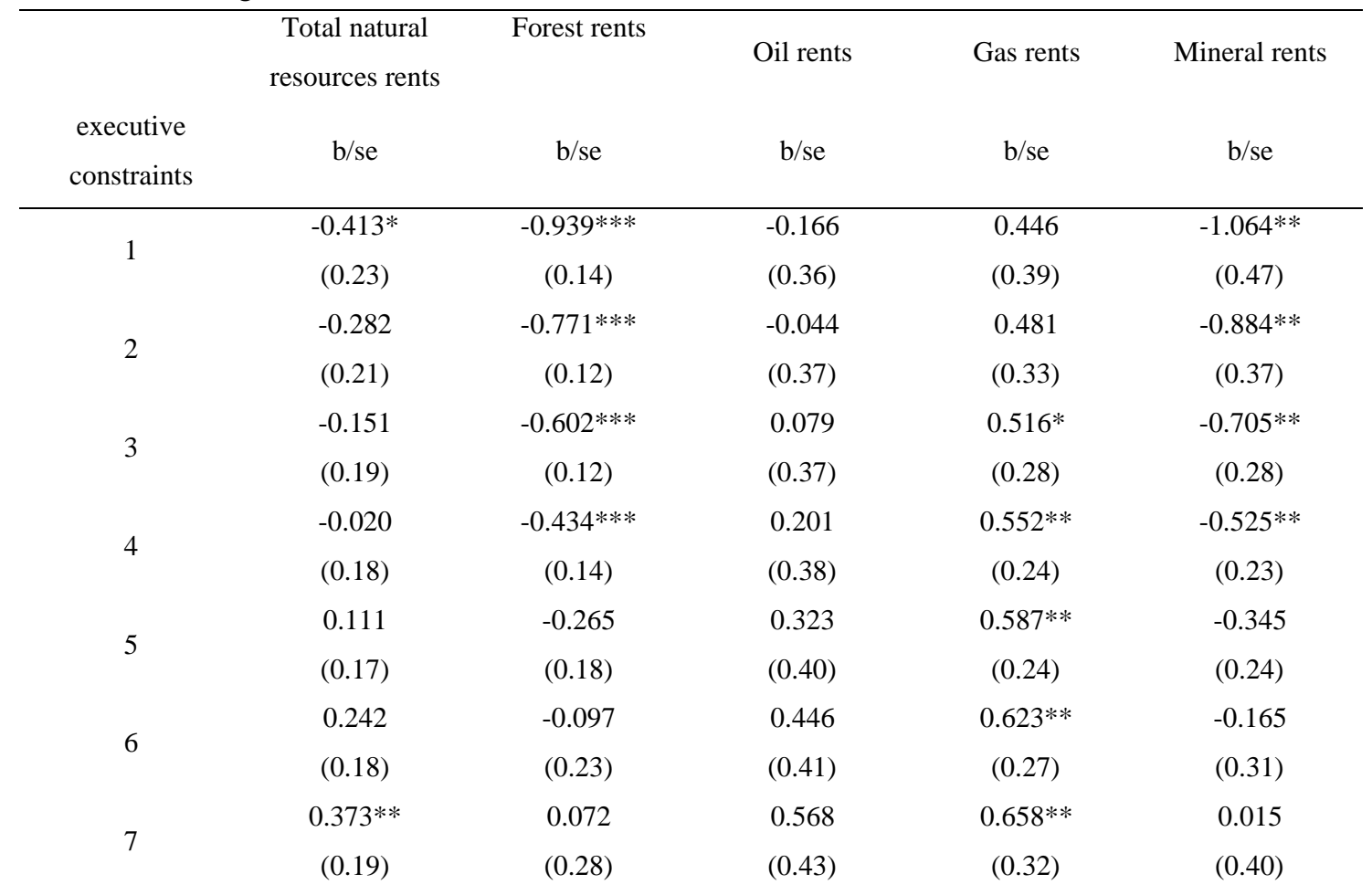

Notes: The marginal effects of Total natural resources rents are calculated using the coefficients from Table 2, Column 5. The marginal effects of forest, oil, gas, and mineral rents are calculated using the coefficients from Table 3, Column 1.

However, these results also suggest that different resource rents may affect fiscal capacity differently. Table 5 shows the marginal effects for each type of resource rent calculated using the coefficients from the first column of Table 3. Interestingly, the largest negative effect on fiscal capacity is mainly due to mineral rents (and then forest rents), but vanishes when the level of executive constraints is at least 4 . This echoes earlier findings on minerals and health outcomes (Edwards 2016), but crucially extends and qualifies them, suggesting that negative effects may not materialise, depending on the nature of political institutions; whereas oil and gas rents either have no effect or can actually foster investments in fiscal infrastructures if the level of executive constraints is high (xconst $\geq 3$ ). Bearing in mind that collinearity may be affecting the standard errors, one can cautiously say that this partly contradicts initial empirical findings on the negative effects of point-source resources, while

\footnotetext{
${ }^{14}$ The related $p$-value for mineral rents is 0.045 . For gas rents is 0.057 , while for both oil and forest rents is 0.000 . This also indicates that collinearity may be spoiling the statistical significance of individual coefficients.
} 
offering some support to those who cast doubt on the apparent curse of oil resources for economic and political development (e.g., Aleexev and Conrad 2009).

\subsection{Robustness checks: the identifying assumption}

The above findings are robust to controlling for all time-invariant variables and for a number of time-varying variables included in the regressions, as well as common trends. However, these results are based on the assumption that resource rents, measured on the basis of international commodity prices, are exogenous to a country's institutions, whereas they may be driven by large commodity producers, who can influence world commodity prices, raising endogeneity concerns with respect to our variable. Therefore, all OPEC members and countries accounting for more than $3 \%$ of total world production of a certain commodity have been excluded from the sample. ${ }^{15}$ In all our key regressions, the result on the heterogonous impact of natural resources proves to be robust (Table 6, columns 5-8).

Finally, we present further robustness checks based on the importance of natural resource rents for the economy. We exclude countries in the top and bottom decile of resource rents. Excluding the bottom and top decile, the baseline results are confirmed.

\footnotetext{
${ }^{15}$ We identify OPEC members and big producers following Caselli and Tesei (2016).
} 
Is there a fiscal resource curse? Resource rents, fiscal capacity and political institutions.

Table 6. Robustness checks - the identifying assumption

\begin{tabular}{|c|c|c|c|c|c|c|c|c|}
\hline & \multicolumn{2}{|c|}{ Excluding bottom decile } & \multicolumn{2}{|c|}{ Excluding top decile } & \multicolumn{2}{|c|}{ Excluding big producers } & \multicolumn{2}{|c|}{ Excluding OPEC countries } \\
\hline VARIABLES & $\begin{array}{c}\text { (1) } \\
\text { Total Rents }\end{array}$ & $\begin{array}{c}(2) \\
\text { Rents }\end{array}$ & $\begin{array}{c}\text { (3) } \\
\text { Total Rents }\end{array}$ & $\begin{array}{c}(4) \\
\text { Rents }\end{array}$ & $\begin{array}{c}\text { (5) } \\
\text { Total Rents }\end{array}$ & (6) & $\begin{array}{c}\text { (7) } \\
\text { Total Rents }\end{array}$ & $(8)$ \\
\hline Executive constraints & $\begin{array}{l}-0.219 \\
(0.548)\end{array}$ & $\begin{array}{l}-0.270 \\
(0.591)\end{array}$ & $\begin{array}{l}-0.617 \\
(0.504)\end{array}$ & $\begin{array}{l}-0.443 \\
(0.619)\end{array}$ & $\begin{array}{l}-0.844^{*} \\
(0.501)\end{array}$ & $\begin{array}{l}-0.872^{*} \\
(0.477)\end{array}$ & $\begin{array}{l}-0.443 \\
(0.516)\end{array}$ & $\begin{array}{l}-0.371 \\
(0.569)\end{array}$ \\
\hline Total natural resources rents & $\begin{array}{l}-0.482^{*} \\
(0.252)\end{array}$ & & $\begin{array}{c}-1.033^{* * * *} \\
(0.346)\end{array}$ & & $\begin{array}{c}-0.832^{* * *} \\
(0.199)\end{array}$ & & $\begin{array}{c}-0.943^{* * *} \\
(0.220)\end{array}$ & \\
\hline $\begin{array}{l}\text { Total natural resources rents*Executive } \\
\text { constraints }\end{array}$ & $\begin{array}{l}0.101^{* * *} \\
(0.0384)\end{array}$ & & $\begin{array}{l}0.173^{* * *} \\
(0.0614)\end{array}$ & & $\begin{array}{l}0.173^{* * *} \\
(0.0408)\end{array}$ & & $\begin{array}{l}0.171^{* * *} \\
(0.0487)\end{array}$ & \\
\hline Forest rents & & $\begin{array}{l}-0.992 * * * \\
(0.179)\end{array}$ & & $\begin{array}{l}-1.529 * * * \\
(0.402)\end{array}$ & & $\begin{array}{c}-1.187 * * * \\
(0.167)\end{array}$ & & $\begin{array}{c}-1.127 * * * \\
(0.186)\end{array}$ \\
\hline Forest rents*Executive constraints & & $\begin{array}{l}0.124^{* *} \\
(0.0608)\end{array}$ & & $\begin{array}{c}0.216 * * * \\
(0.0771)\end{array}$ & & $\begin{array}{c}0.216^{* * *} \\
(0.0557)\end{array}$ & & $\begin{array}{l}0.173^{* * *} \\
(0.0598)\end{array}$ \\
\hline Oil rents & & $\begin{array}{l}-0.237 \\
(0.366)\end{array}$ & & $\begin{array}{l}-0.248 \\
(0.502)\end{array}$ & & $\begin{array}{l}-0.429 \\
(0.427)\end{array}$ & & $\begin{array}{l}-0.759 \\
(0.610)\end{array}$ \\
\hline Oil rents*Executive constraints & & $\begin{array}{l}0.101^{* *} \\
(0.0425)\end{array}$ & & $\begin{array}{c}0.00158 \\
(0.101)\end{array}$ & & $\begin{array}{c}0.104^{*} \\
(0.0551)\end{array}$ & & $\begin{array}{c}0.101 \\
(0.173)\end{array}$ \\
\hline Gas rents & & $\begin{array}{c}0.337 \\
(0.377)\end{array}$ & & $\begin{array}{l}-0.186 \\
(1.323)\end{array}$ & & $\begin{array}{l}-0.646 \\
(0.451)\end{array}$ & & $\begin{array}{l}0.0328 \\
(0.365)\end{array}$ \\
\hline Gas rents*Executive constraints & & $\begin{array}{c}0.0318 \\
(0.0707)\end{array}$ & & $\begin{array}{c}0.142 \\
(0.191)\end{array}$ & & $\begin{array}{l}0.563^{* *} \\
(0.267)\end{array}$ & & $\begin{array}{c}0.102 \\
(0.0697)\end{array}$ \\
\hline Mineral rents & & $\begin{array}{l}-1.152^{*} \\
(0.605)\end{array}$ & & $\begin{array}{l}-1.314^{*} \\
(0.702)\end{array}$ & & $\begin{array}{c}-1.200 * * \\
(0.555)\end{array}$ & & $\begin{array}{c}-1.418^{* *} \\
(0.580)\end{array}$ \\
\hline Mineral rents*Executive constraints & & $\begin{array}{c}0.142 \\
(0.130)\end{array}$ & & $\begin{array}{c}0.183 \\
(0.143)\end{array}$ & & $\begin{array}{c}0.216 \\
(0.143)\end{array}$ & & $\begin{array}{c}0.208 \\
(0.126)\end{array}$ \\
\hline Political Stability & $\begin{array}{c}0.613 \\
(0.948)\end{array}$ & $\begin{array}{c}0.413 \\
(0.995)\end{array}$ & $\begin{array}{c}0.227 \\
(0.939)\end{array}$ & $\begin{array}{c}0.680 \\
(1.012)\end{array}$ & $\begin{array}{l}-0.282 \\
(0.861)\end{array}$ & $\begin{array}{l}-0.0825 \\
(0.819)\end{array}$ & $\begin{array}{c}0.782 \\
(0.934)\end{array}$ & $\begin{array}{c}0.798 \\
(0.974)\end{array}$ \\
\hline External Debt & $\begin{array}{c}-0.0163^{* * * *} \\
(0.00595)\end{array}$ & $\begin{array}{c}-0.0133^{* *} \\
(0.00515)\end{array}$ & $\begin{array}{l}-0.0181^{* *} \\
(0.00694)\end{array}$ & $\begin{array}{l}-0.0149 * * \\
(0.00691)\end{array}$ & $\begin{array}{c}-0.0141^{* * * *} \\
(0.00504)\end{array}$ & $\begin{array}{l}-0.0110 * * \\
(0.00481)\end{array}$ & $\begin{array}{c}-0.0123^{* *} \\
(0.00507)\end{array}$ & $\begin{array}{c}-0.0113^{* *} \\
(0.00481)\end{array}$ \\
\hline Trade & $\begin{array}{c}0.0262 \\
(0.0305)\end{array}$ & $\begin{array}{c}0.0248 \\
(0.0321)\end{array}$ & $\begin{array}{c}0.0195 \\
(0.0371)\end{array}$ & $\begin{array}{c}0.0203 \\
(0.0368)\end{array}$ & $\begin{array}{l}0.00921 \\
(0.0312)\end{array}$ & $\begin{array}{r}-0.00408 \\
(0.0317)\end{array}$ & $\begin{array}{l}0.00757 \\
(0.0323)\end{array}$ & $\begin{array}{l}0.00758 \\
(0.0326)\end{array}$ \\
\hline Net ODA and aid per capita & $\begin{array}{l}-0.0118 \\
(0.0150)\end{array}$ & $\begin{array}{r}-0.00957 \\
(0.0169)\end{array}$ & $\begin{array}{l}-0.0178 \\
(0.0128)\end{array}$ & $\begin{array}{c}-0.0114 \\
(0.0158)\end{array}$ & $\begin{array}{c}-0.0199 \\
(0.0152)\end{array}$ & $\begin{array}{c}-0.0209 \\
(0.0165)\end{array}$ & $\begin{array}{c}-0.0159 \\
(0.0139)\end{array}$ & $\begin{array}{l}-0.0152 \\
(0.0158)\end{array}$ \\
\hline Population density & $\begin{array}{l}0.0498^{*} \\
(0.0281)\end{array}$ & $\begin{array}{l}0.0470^{*} \\
(0.0268)\end{array}$ & $\begin{array}{c}0.0793^{* * *} \\
(0.0299)\end{array}$ & $\begin{array}{c}0.0722 * * \\
(0.0295)\end{array}$ & $\begin{array}{c}0.0737 * * * \\
(0.0276)\end{array}$ & $\begin{array}{c}0.0667 * * \\
(0.0266)\end{array}$ & $\begin{array}{l}0.0721 * * \\
(0.0284)\end{array}$ & $\begin{array}{r}0.0673^{* *} \\
(0.0280)\end{array}$ \\
\hline External conflict & $\begin{array}{l}1.044^{*} \\
(0.541)\end{array}$ & $\begin{array}{c}0.855 \\
(0.534)\end{array}$ & $\begin{array}{c}0.301 \\
(0.702)\end{array}$ & $\begin{array}{c}0.103 \\
(0.725)\end{array}$ & $\begin{array}{c}0.382 \\
(0.733)\end{array}$ & $\begin{array}{c}0.234 \\
(0.759)\end{array}$ & $\begin{array}{c}0.267 \\
(0.716)\end{array}$ & $\begin{array}{c}0.159 \\
(0.722)\end{array}$ \\
\hline Civil war & $\begin{array}{l}-2.229 * \\
(1.130)\end{array}$ & $\begin{array}{c}-2.382^{* *} \\
(1.161)\end{array}$ & $\begin{array}{c}-2.927^{* *} \\
(1.360)\end{array}$ & $\begin{array}{l}-2.675 * \\
(1.367)\end{array}$ & $\begin{array}{l}-2.108 \\
(1.326)\end{array}$ & $\begin{array}{l}-1.999 \\
(1.324)\end{array}$ & $\begin{array}{c}-3.038 * * \\
(1.346)\end{array}$ & $\begin{array}{c}-2.975 * * \\
(1.356)\end{array}$ \\
\hline Constant & $\begin{array}{c}25.11^{* * *} \\
(5.696)\end{array}$ & $\begin{array}{c}27.32 * * * \\
(5.717)\end{array}$ & $\begin{array}{c}30.33^{* * * *} \\
(6.266)\end{array}$ & $\begin{array}{c}28.59 * * * \\
(6.954)\end{array}$ & $\begin{array}{c}33.63^{* * * *} \\
(5.864)\end{array}$ & $\begin{array}{c}34.31^{* * *} \\
(5.533)\end{array}$ & $\begin{array}{c}29.53^{* * * *} \\
(6.412)\end{array}$ & $\begin{array}{c}30.29 * * * \\
(6.862)\end{array}$ \\
\hline Observations & 313 & 313 & 315 & 315 & 296 & 296 & 326 & 326 \\
\hline Number of countries & 84 & 84 & 79 & 79 & 78 & 78 & 84 & 84 \\
\hline Adjusted R-squared & 0.232 & 0.270 & 0.203 & 0.218 & 0.222 & 0.249 & 0.217 & 0.227 \\
\hline Year FE & YES & YES & YES & YES & YES & YES & YES & YES \\
\hline Joint(p) & 0.0354 & $1.38 \mathrm{e}-08$ & 0.0140 & 0.000383 & $5.81 \mathrm{e}-05$ & $2.22 \mathrm{e}-10$ & 0.000255 & $6.07 e-07$ \\
\hline
\end{tabular}

Notes: The dependent variable is non-resource income tax as a percentage of non-resource total tax revenue. Robust standard errors in parentheses.

Notes: The dependent variable is 
Table 7. Marginal effects of resource rents at different levels of executive constraints Excluding bottom decile

\begin{tabular}{|c|c|c|c|c|c|}
\hline \multirow[b]{2}{*}{$\begin{array}{l}\text { Executive } \\
\text { constraints }\end{array}$} & $\begin{array}{l}\text { Total natural } \\
\text { resources rents }\end{array}$ & Forest rents & Oil rents & Gas rents & Mineral rents \\
\hline & $\mathrm{b} / \mathrm{se}$ & b/se & $\mathrm{b} / \mathrm{se}$ & $\mathrm{b} / \mathrm{se}$ & $\mathrm{b} / \mathrm{se}$ \\
\hline \multirow{2}{*}{1} & $-0.381^{*}$ & $-0.868 * * *$ & -0.136 & 0.369 & $-1.010 * *$ \\
\hline & $(0.23)$ & $(0.14)$ & $(0.36)$ & $(0.32)$ & $(0.49)$ \\
\hline \multirow{2}{*}{2} & -0.280 & $-0.744 * * *$ & -0.034 & 0.401 & $-0.869 * *$ \\
\hline & $(0.20)$ & $(0.11)$ & $(0.37)$ & $(0.27)$ & $(0.38)$ \\
\hline \multirow{2}{*}{3} & -0.179 & $-0.620 * * *$ & 0.067 & $0.433^{*}$ & $-0.727 * *$ \\
\hline & $(0.18)$ & $(0.12)$ & $(0.38)$ & $(0.23)$ & $(0.29)$ \\
\hline \multirow{2}{*}{4} & -0.077 & $-0.496 * * *$ & 0.168 & $0.464 * *$ & $-0.585^{* *}$ \\
\hline & $(0.17)$ & $(0.15)$ & (0.39) & $(0.21)$ & $(0.23)$ \\
\hline \multirow{2}{*}{5} & 0.024 & $-0.371^{*}$ & 0.269 & $0.496 * *$ & $-0.444^{*}$ \\
\hline & $(0.17)$ & $(0.20)$ & $(0.40)$ & $(0.21)$ & $(0.25)$ \\
\hline \multirow{2}{*}{6} & 0.125 & -0.247 & 0.371 & $0.528 * *$ & -0.302 \\
\hline & $(0.18)$ & $(0.25)$ & $(0.42)$ & $(0.24)$ & $(0.32)$ \\
\hline \multirow{2}{*}{7} & 0.226 & -0.123 & 0.472 & $0.560^{* *}$ & -0.161 \\
\hline & (0.19) & $(0.30)$ & $(0.45)$ & $(0.28)$ & $(0.42)$ \\
\hline
\end{tabular}

Notes: The marginal effects of specific natural resources are calculated using the coefficients from Table 6 , Columns 1 and 2 .

Table 8. Marginal effects of resource rents at different levels of executive constraints -Excluding top decile

\begin{tabular}{|c|c|c|c|c|c|}
\hline \multirow[b]{2}{*}{$\begin{array}{l}\text { Executive } \\
\text { constraints }\end{array}$} & $\begin{array}{l}\text { Total natural } \\
\text { resources rents }\end{array}$ & Forest rents & Oil rents & Gas rents & Mineral rents \\
\hline & b/se & b/se & b/se & $\mathrm{b} / \mathrm{se}$ & $\mathrm{b} / \mathrm{se}$ \\
\hline \multirow{2}{*}{1} & $-0.860 * * *$ & $-1.313 * * *$ & -0.247 & -0.044 & $-1.131 * *$ \\
\hline & $(0.29)$ & $(0.34)$ & $(0.45)$ & (1.14) & $(0.57)$ \\
\hline \multirow{2}{*}{2} & $-0.687 * * *$ & $-1.097 * * *$ & -0.245 & 0.098 & $-0.948 * *$ \\
\hline & $(0.24)$ & $(0.30)$ & $(0.42)$ & (0.95) & $(0.45)$ \\
\hline \multirow{2}{*}{3} & $-0.515 * * *$ & $-0.882 * * *$ & -0.243 & 0.240 & $-0.766 * *$ \\
\hline & $(0.20)$ & $(0.26)$ & $(0.41)$ & (0.77) & (0.34) \\
\hline \multirow{2}{*}{4} & $-0.342 * *$ & $-0.666 * * *$ & -0.242 & 0.381 & $-0.583 * *$ \\
\hline & $(0.17)$ & $(0.25)$ & $(0.43)$ & (0.59) & $(0.27)$ \\
\hline \multirow{2}{*}{5} & -0.169 & $-0.450 *$ & -0.240 & 0.523 & -0.400 \\
\hline & $(0.15)$ & $(0.26)$ & $(0.46)$ & $(0.43)$ & $(0.27)$ \\
\hline \multirow{2}{*}{6} & 0.004 & -0.234 & -0.239 & $0.665^{* *}$ & -0.217 \\
\hline & $(0.16)$ & $(0.29)$ & $(0.52)$ & $(0.30)$ & $(0.33)$ \\
\hline \multirow{2}{*}{7} & 0.176 & -0.019 & -0.237 & $0.807 * * *$ & -0.035 \\
\hline & $(0.20)$ & $(0.33)$ & $(0.58)$ & $(0.27)$ & $(0.44)$ \\
\hline
\end{tabular}

Notes: The marginal effects of specific natural resources are calculated using the coefficients from Table 6 , Columns 3 and 4 . 
Table 9. Marginal effects of resource rents at different levels of executive constraints Excluding big producers

\begin{tabular}{|c|c|c|c|c|c|}
\hline \multirow[b]{2}{*}{$\begin{array}{l}\text { Executive } \\
\text { constraints }\end{array}$} & $\begin{array}{c}\text { Total natural } \\
\text { resources rents }\end{array}$ & Forest rents & Oil rents & Gas rents & Mineral rents \\
\hline & b/se & $\mathrm{b} / \mathrm{se}$ & b/se & $\mathrm{b} / \mathrm{se}$ & $\mathrm{b} / \mathrm{se}$ \\
\hline \multirow{2}{*}{1} & $-0.659 * * *$ & $-0.971 * * *$ & -0.325 & -0.083 & $-0.985^{* *}$ \\
\hline & $(0.18)$ & (0.13) & $(0.40)$ & $(0.33)$ & $(0.43)$ \\
\hline \multirow{2}{*}{2} & $-0.487 * * *$ & $-0.755^{* * *}$ & -0.221 & 0.480 & $-0.769 * *$ \\
\hline & $(0.16)$ & $(0.10)$ & $(0.38)$ & (0.39) & (0.33) \\
\hline \multirow{2}{*}{3} & $-0.314^{*}$ & $-0.539 * * *$ & -0.116 & $1.043^{*}$ & $-0.553 * *$ \\
\hline & $(0.16)$ & $(0.10)$ & $(0.37)$ & $(0.58)$ & $(0.26)$ \\
\hline \multirow{2}{*}{4} & -0.141 & $-0.323 * *$ & -0.012 & $1.606^{* *}$ & -0.338 \\
\hline & $(0.17)$ & (0.13) & (0.37) & $(0.82)$ & $(0.26)$ \\
\hline \multirow{2}{*}{5} & 0.031 & -0.107 & 0.092 & $2.169 * *$ & -0.122 \\
\hline & $(0.18)$ & $(0.17)$ & $(0.37)$ & (1.07) & $(0.34)$ \\
\hline \multirow{2}{*}{6} & 0.204 & 0.109 & 0.196 & $2.732 * *$ & 0.094 \\
\hline & $(0.20)$ & $(0.22)$ & $(0.38)$ & (1.33) & $(0.44)$ \\
\hline \multirow{2}{*}{7} & 0.377 & 0.325 & 0.300 & $3.295^{* *}$ & 0.310 \\
\hline & $(0.23)$ & $(0.27)$ & $(0.40)$ & (1.59) & $(0.57)$ \\
\hline
\end{tabular}

Notes: The marginal effects of specific natural resources are calculated using the coefficients from Table 6, Columns 5 and 6 .

Table 10. Marginal effects of resource rents at different levels of executive constraints - Excluding OPEC countries

\begin{tabular}{|c|c|c|c|c|c|}
\hline \multirow[b]{2}{*}{$\begin{array}{l}\text { Executive } \\
\text { constraints }\end{array}$} & $\begin{array}{c}\text { Total natural } \\
\text { resources rents }\end{array}$ & Forest rents & Oil rents & Gas rents & Mineral rents \\
\hline & $\mathrm{b} / \mathrm{se}$ & $\mathrm{b} / \mathrm{se}$ & b/se & b/se & b/se \\
\hline \multirow{2}{*}{1} & $-0.772 * * *$ & $-0.954 * * *$ & $\begin{array}{l}-0.658 \\
\end{array}$ & 0.135 & $-1.209 * * *$ \\
\hline & $(0.18)$ & $(0.14)$ & $(0.47)$ & $(0.32)$ & $(0.46)$ \\
\hline \multirow{2}{*}{2} & $-0.601 * * *$ & $-0.781 * * *$ & -0.556 & 0.237 & $-1.001 * * *$ \\
\hline & $(0.15)$ & $(0.12)$ & $(0.36)$ & $(0.28)$ & $(0.36)$ \\
\hline \multirow{2}{*}{3} & $-0.430 * * *$ & $-0.607 * * *$ & -0.455 & 0.339 & $-0.793 * * *$ \\
\hline & $(0.13)$ & $(0.12)$ & $(0.31)$ & $(0.25)$ & $(0.26)$ \\
\hline \multirow{2}{*}{4} & $-0.259 * *$ & $-0.434 * * *$ & -0.353 & $0.442 *$ & $-0.584 * * *$ \\
\hline & $(0.12)$ & $(0.14)$ & $(0.36)$ & $(0.24)$ & $(0.21)$ \\
\hline \multirow{2}{*}{5} & -0.088 & -0.261 & -0.252 & $0.544^{* *}$ & $-0.376^{*}$ \\
\hline & $(0.13)$ & $(0.19)$ & $(0.46)$ & $(0.26)$ & $(0.23)$ \\
\hline \multirow{2}{*}{6} & 0.083 & -0.088 & -0.151 & $0.646^{* *}$ & -0.168 \\
\hline & $(0.16)$ & $(0.24)$ & $(0.60)$ & $(0.28)$ & $(0.30)$ \\
\hline \multirow{2}{*}{7} & 0.254 & 0.086 & -0.049 & $0.748^{* *}$ & 0.041 \\
\hline & $(0.20)$ & $(0.29)$ & $(0.75)$ & (0.33) & $(0.40)$ \\
\hline
\end{tabular}

Notes: The marginal effects of specific natural resources are calculated using the coefficients from Table 6, Columns 7 and 8 .. 


\subsection{How do resource rents affect fiscal capacity?}

Our findings indicate that political institutions limiting executive power create the conditions to offset (or even reverse) the negative effects that natural resource abundance can have on fiscal systems. However, we have not identified hitherto which specific fiscal institutions are affected, an exercise that could deliver insights on the channels of causation. Here we do consider two possible channels. Unpacking the concept of fiscal capacity, we distinguish between two aspects of tax systems: the accountability and transparency of such institutions, impartiality, and their effectiveness in extracting revenues.

Impartiality concerns fairness in the exercise of taxation powers: it is the ability of tax systems to make the state accountable to, and transparent for, its citizens, and so building state-society relations conducive to quasi-compliance (e.g., Levi, 1988). The other concerns their effectiveness in raising tax revenues, i.e., the ability to coerce citizens to pay taxes. Outcome-based measures of fiscal capacity, such as the tax-to-GDP ratio or the measure used so far, cannot differentiate between these two quite different dimensions of fiscal systems related to the exercise of taxation powers.

To test whether a fiscal resource curse works through impartiality or effectiveness (or both), we use a recently created set of indicators provided by PEFA (2006), the Public Expenditure and Financial Accountability project developed by a partnership of national and international organisations (e.g., IMF and the World Bank). In particular, we use five indicators selected from the PEFA database, neatly capturing the impartiality and effectiveness of tax systems. They are described below: ${ }^{16}$

1. Transparency of taxpayer obligations and liabilities, which evaluates taxpayers' access to information on tax liabilities and administrative procedures;

2. Tax appeals: assessing the functioning of a tax appeals mechanism;

3. Controls in the taxpayer registration system, assessing the quality and maintenance of a taxpayer database;

4. Effectiveness of penalties for non-compliance: this addresses failures in registration and tax declaration obligations, assessing whether penalties for all areas of non-

\footnotetext{
${ }^{16}$ Full details of the PEFA framework, indicators and assessment method are given in the database codebook at https://pefa.org/sites/default/files/PMFEng-finalSZreprint04-12 1.pdf.To save space, we only report the scoring method for Tax appeals: 3. A tax appeals system of transparent administrative procedures with appropriate checks and balances, and implemented through independent institutional structures, is completely set up and effectively operating with satisfactory access and fairness, and its decisions are promptly acted upon. 2. A tax appeals system of transparent administrative procedures is completely set up and functional, but it is either too early to assess its effectiveness or some issues relating to access, efficiency, fairness or effective follow-up on its decisions need to be addressed. 1. A tax appeals system of administrative procedures has been established, but needs substantial redesign to be fair, transparent and effective. 0 . No functioning tax appeals system has been established.

Apart from the PEFA variables used here, we experiment with two further effectiveness measures (one looking at the effectiveness of transfer of tax collections to the Treasury by the revenue administration, the other looking at the frequency of complete accounts reconciliation between tax assessments, collections, arrears records and receipts by the Treasury), finding that the effects of resource rents are not robust.
} 
compliance are set sufficiently high to act as deterrence and are consistently administered;

5. Quality of tax audit evaluates whether and how tax audits and fraud investigations are undertaken;

The first two indicators capture the impartiality of fiscal capacity, since they hinge on the relationship between the state and the public: empowering it against the taxation power of the former or making such power clearly defined and not subject to discretion. The final three measures assess the coercive aspects of the tax system: they are all desirable features of a tax machine aiming at raising revenues. ${ }^{17}$ Higher scores indicate greater levels of fiscal capacity: both impartiality and effectiveness. Below we estimate an OLS cross-section version of (1), for over 60 developing economies, where each of the above measures acts as a dependent variable. ${ }^{18}$ The results (Tables 11 and 12) suggest that, to some extent, the interaction between political institutions and resource rents affects the transparency of taxpayer obligations and liability only.

\footnotetext{
${ }^{17}$ Methodologically, these are de facto measures: what matters is the actual working of the system and not what is merely written in the law. This ensures that the assessment is based on institutional reforms, reacting to the pressure of external authorities, to some degree internalised by those who implement them.

${ }^{18}$ Although the PEFA dataset is gradually expanding, its structure is such that it does not yet allow for panel analysis. In particular, PEFA variables range only from 2005 to 2013 and have a T-bar of 1.5, as well as exhibiting very little variation within countries.
} 
Is there a fiscal resource curse? Resource rents, fiscal capacity and political institutions.

Table 11. Tests of possible channels of causation from resource rents to fiscal capacity

\begin{tabular}{|c|c|c|c|c|c|c|c|c|c|c|}
\hline $\begin{array}{l}\text { DEPENDENT } \\
\text { VARIABLES }\end{array}$ & $\begin{array}{c}\text { (1) } \\
\text { Transparency } \\
\text { of taxpayer } \\
\text { obligations } \\
\text { and liabilities }\end{array}$ & $\begin{array}{c}\text { (2) } \\
\text { Transparency } \\
\text { of taxpayer } \\
\text { obligations } \\
\text { and liabilities }\end{array}$ & $\begin{array}{c}\text { (3) } \\
\text { Tax appeals }\end{array}$ & $\begin{array}{c}(4) \\
\text { Tax appeals }\end{array}$ & $\begin{array}{l}\text { (5) } \\
\text { Controls in } \\
\text { the taxpayer } \\
\text { registration } \\
\text { system }\end{array}$ & $\begin{array}{c}\text { (6) } \\
\text { Controls in } \\
\text { the taxpayer } \\
\text { registration } \\
\text { system }\end{array}$ & $\begin{array}{c}(7) \\
\text { Effectiveness } \\
\text { of penalties } \\
\text { for non- } \\
\text { compliance } \\
\text { with } \\
\text { registration } \\
\text { and tax } \\
\text { declaration } \\
\end{array}$ & $\begin{array}{c}(8) \\
\text { Effectiveness } \\
\text { of penalties } \\
\text { for non- } \\
\text { compliance } \\
\text { with } \\
\text { registration } \\
\text { and tax } \\
\text { declaration } \\
\end{array}$ & $\begin{array}{c}\text { (9) } \\
\text { Quality of } \\
\text { tax audit }\end{array}$ & $\begin{array}{c}(10) \\
\text { Quality of } \\
\text { tax audit }\end{array}$ \\
\hline Total natural resources rents & $\begin{array}{l}-0.00945 \\
(0.00982)\end{array}$ & $\begin{array}{c}-0.0409 * * \\
(0.0162)\end{array}$ & $\begin{array}{l}-0.00498 \\
(0.0103)\end{array}$ & $\begin{array}{l}-0.0229 \\
(0.0212)\end{array}$ & $\begin{array}{l}-0.00881 \\
(0.00836)\end{array}$ & $\begin{array}{l}-0.00135 \\
(0.0193)\end{array}$ & $\begin{array}{l}-0.0116 \\
(0.0160)\end{array}$ & $\begin{array}{l}-0.0437 * \\
(0.0225)\end{array}$ & $\begin{array}{c}-0.000753 \\
(0.0116)\end{array}$ & $\begin{array}{l}0.00435 \\
(0.0170)\end{array}$ \\
\hline Executive constraints & $\begin{array}{c}0.148 \\
(0.0898)\end{array}$ & $\begin{array}{c}0.0659 \\
(0.0997)\end{array}$ & $\begin{array}{c}0.244 * * * \\
(0.0822)\end{array}$ & $\begin{array}{l}0.197 * * \\
(0.0879)\end{array}$ & $\begin{array}{c}0.295 * * * \\
(0.0653)\end{array}$ & $\begin{array}{c}0.315 * * * \\
(0.0778)\end{array}$ & $\begin{array}{l}0.238 * * \\
(0.0925)\end{array}$ & $\begin{array}{c}0.154 \\
(0.0998)\end{array}$ & $\begin{array}{c}0.108 \\
(0.0827)\end{array}$ & $\begin{array}{c}0.121 \\
(0.0945)\end{array}$ \\
\hline Tot. res rents*Ex. constraints & & $\begin{array}{l}0.0118 * * \\
(0.00449)\end{array}$ & & $\begin{array}{c}0.00670 \\
(0.00643)\end{array}$ & & $\begin{array}{l}-0.00280 \\
(0.00574)\end{array}$ & & $\begin{array}{c}0.0121 * \\
(0.00629)\end{array}$ & & $\begin{array}{l}-0.00192 \\
(0.00388)\end{array}$ \\
\hline Political stability & $\begin{array}{l}0.0367 \\
(0.144)\end{array}$ & $\begin{array}{c}0.000691 \\
(0.145)\end{array}$ & $\begin{array}{c}0.108 \\
(0.111)\end{array}$ & $\begin{array}{l}0.0875 \\
(0.112)\end{array}$ & $\begin{array}{l}-0.0605 \\
(0.133)\end{array}$ & $\begin{array}{l}-0.0520 \\
(0.134)\end{array}$ & $\begin{array}{l}0.0680 \\
(0.153)\end{array}$ & $\begin{array}{l}0.0308 \\
(0.161)\end{array}$ & $\begin{array}{c}-0.325^{* *} \\
(0.128)\end{array}$ & $\begin{array}{c}-0.319 * * \\
(0.132)\end{array}$ \\
\hline Net ODA and aid per capita & $\begin{array}{l}0.000181 \\
(0.00155)\end{array}$ & $\begin{array}{l}0.000630 \\
(0.00150)\end{array}$ & $\begin{array}{c}-0.00250 * * * \\
(0.000931)\end{array}$ & $\begin{array}{l}-0.00224^{* *} \\
(0.000915)\end{array}$ & $\begin{array}{l}0.000219 \\
(0.00155)\end{array}$ & $\begin{array}{l}0.000113 \\
(0.00160)\end{array}$ & $\begin{array}{l}-6.41 \mathrm{e}-05 \\
(0.00171)\end{array}$ & $\begin{array}{l}0.000393 \\
(0.00167)\end{array}$ & $\begin{array}{l}0.000312 \\
(0.00208)\end{array}$ & $\begin{array}{l}0.000239 \\
(0.00213)\end{array}$ \\
\hline Population density & $\begin{array}{c}0.000531 \\
(0.000754)\end{array}$ & $\begin{array}{c}0.000557 \\
(0.000716)\end{array}$ & $\begin{array}{c}0.000152 \\
(0.000720)\end{array}$ & $\begin{array}{c}0.000167 \\
(0.000667)\end{array}$ & $\begin{array}{c}-0.000229 \\
(0.000450)\end{array}$ & $\begin{array}{l}-0.000235 \\
(0.000459)\end{array}$ & $\begin{array}{c}-0.000169 \\
(0.000604)\end{array}$ & $\begin{array}{c}-0.000138 \\
(0.000552)\end{array}$ & $\begin{array}{c}0.000445 \\
(0.000596)\end{array}$ & $\begin{array}{c}0.000440 \\
(0.000592)\end{array}$ \\
\hline External conflict & $\begin{array}{l}0.283 * * \\
(0.137)\end{array}$ & $\begin{array}{l}0.297 * * \\
(0.136)\end{array}$ & $\begin{array}{c}0.177 \\
(0.123)\end{array}$ & $\begin{array}{c}0.185 \\
(0.125)\end{array}$ & $\begin{array}{l}0.0928 \\
(0.138)\end{array}$ & $\begin{array}{l}0.0894 \\
(0.140)\end{array}$ & $\begin{array}{c}0.178 \\
(0.112)\end{array}$ & $\begin{array}{l}0.193 * \\
(0.112)\end{array}$ & $\begin{array}{c}0.171 \\
(0.127)\end{array}$ & $\begin{array}{c}0.169 \\
(0.129)\end{array}$ \\
\hline Civil war & $\begin{array}{c}-0.0363 \\
(0.237)\end{array}$ & $\begin{array}{l}-0.0326 \\
(0.230)\end{array}$ & $\begin{array}{l}0.0328 \\
(0.212)\end{array}$ & $\begin{array}{l}0.0349 \\
(0.217)\end{array}$ & $\begin{array}{c}0.126 \\
(0.259)\end{array}$ & $\begin{array}{c}0.125 \\
(0.264)\end{array}$ & $\begin{array}{l}-0.182 \\
(0.203)\end{array}$ & $\begin{array}{l}-0.179 \\
(0.203)\end{array}$ & $\begin{array}{c}0.175 \\
(0.193)\end{array}$ & $\begin{array}{c}0.174 \\
(0.196)\end{array}$ \\
\hline Length of statehood & $\begin{array}{c}0.00439 \\
(0.00517)\end{array}$ & $\begin{array}{c}0.00522 \\
(0.00519)\end{array}$ & $\begin{array}{c}0.00440 \\
(0.00412)\end{array}$ & $\begin{array}{c}0.00488 \\
(0.00407)\end{array}$ & $\begin{array}{l}0.000380 \\
(0.00269)\end{array}$ & $\begin{array}{l}0.000182 \\
(0.00278)\end{array}$ & $\begin{array}{c}0.00626 \\
(0.00550)\end{array}$ & $\begin{array}{c}0.00715 \\
(0.00527)\end{array}$ & $\begin{array}{c}0.00563 \\
(0.00370)\end{array}$ & $\begin{array}{c}0.00549 \\
(0.00378)\end{array}$ \\
\hline Constant & $\begin{array}{c}0.589 \\
(0.834)\end{array}$ & $\begin{array}{c}0.923 \\
(0.864)\end{array}$ & $\begin{array}{l}-0.266 \\
(0.745)\end{array}$ & $\begin{array}{l}-0.0762 \\
(0.769)\end{array}$ & $\begin{array}{c}0.622 \\
(0.805)\end{array}$ & $\begin{array}{c}0.542 \\
(0.826)\end{array}$ & $\begin{array}{c}0.350 \\
(0.936)\end{array}$ & $\begin{array}{c}0.690 \\
(1.001)\end{array}$ & $\begin{array}{l}1.501^{*} \\
(0.881)\end{array}$ & $\begin{array}{c}1.447 \\
(0.912)\end{array}$ \\
\hline $\begin{array}{l}\text { Observations } \\
\text { Adjusted R-squared } \\
\text { Joint(p) }\end{array}$ & $\begin{array}{c}61 \\
0.206\end{array}$ & $\begin{array}{c}61 \\
0.236 \\
0.0380\end{array}$ & $\begin{array}{c}61 \\
0.234\end{array}$ & $\begin{array}{c}61 \\
0.238 \\
0.553\end{array}$ & $\begin{array}{c}61 \\
0.278\end{array}$ & $\begin{array}{c}61 \\
0.266 \\
0.434\end{array}$ & $\begin{array}{c}62 \\
0.110\end{array}$ & $\begin{array}{c}62 \\
0.136 \\
0.127\end{array}$ & $\begin{array}{c}62 \\
0.344\end{array}$ & $\begin{array}{c}62 \\
0.332 \\
0.874\end{array}$ \\
\hline
\end{tabular}

Notes: The dependent variable is calculated as 2006-2011 average. Robust standard errors in parentheses. ${ }^{* * *} p<0.01,{ }^{* *} p<0.05,{ }^{*} p<0.1$. 
Table 12. Effects of resource rents on fiscal capacity at different levels of executive

\begin{tabular}{|c|c|c|c|c|c|}
\hline \multicolumn{6}{|c|}{ constraints } \\
\hline \multirow[b]{2}{*}{$\begin{array}{l}\text { Executive } \\
\text { constraints }\end{array}$} & $\begin{array}{c}\text { Transparency of } \\
\text { taxpayer } \\
\text { obligations and } \\
\text { liabilities }\end{array}$ & $\begin{array}{l}\text { Tax appeals } \\
\text { mechanisms }\end{array}$ & $\begin{array}{l}\text { Controls in the } \\
\text { taxpayer } \\
\text { registration } \\
\text { system }\end{array}$ & $\begin{array}{l}\text { Effectiveness of } \\
\text { penalties for } \\
\text { non-compliance } \\
\text { with registration } \\
\text { and tax } \\
\text { declaration }\end{array}$ & $\begin{array}{l}\text { Quality of tax } \\
\text { audit }\end{array}$ \\
\hline & $\mathrm{b} / \mathrm{se}$ & $\mathrm{b} / \mathrm{se}$ & $\mathrm{b} / \mathrm{se}$ & $\mathrm{b} / \mathrm{se}$ & $\mathrm{b} / \mathrm{se}$ \\
\hline \multirow{2}{*}{1} & $-0.029 * *$ & -0.016 & -0.004 & $-0.032 *$ & 0.002 \\
\hline & $(0.01)$ & $(0.02)$ & $(0.01)$ & $(0.02)$ & $(0.01)$ \\
\hline \multirow{2}{*}{2} & $-0.017^{*}$ & -0.009 & -0.007 & -0.020 & 0.001 \\
\hline & $(0.01)$ & $(0.01)$ & $(0.01)$ & $(0.02)$ & $(0.01)$ \\
\hline \multirow{2}{*}{3} & -0.006 & -0.003 & -0.010 & -0.007 & -0.001 \\
\hline & $(0.01)$ & $(0.01)$ & $(0.01)$ & $(0.02)$ & $(0.01)$ \\
\hline \multirow{2}{*}{4} & 0.006 & 0.004 & -0.013 & 0.005 & -0.003 \\
\hline & $(0.01)$ & $(0.01)$ & $(0.01)$ & $(0.02)$ & $(0.01)$ \\
\hline \multirow{2}{*}{5} & $0.018 *$ & 0.011 & -0.015 & 0.017 & -0.005 \\
\hline & $(0.01)$ & $(0.02)$ & $(0.01)$ & $(0.02)$ & $(0.01)$ \\
\hline \multirow{2}{*}{6} & $0.030 * *$ & 0.017 & -0.018 & 0.029 & -0.007 \\
\hline & $(0.01)$ & $(0.02)$ & $(0.02)$ & $(0.03)$ & $(0.02)$ \\
\hline \multirow{2}{*}{7} & $0.042 * *$ & 0.024 & -0.021 & 0.041 & -0.009 \\
\hline & $(0.02)$ & $(0.03)$ & $(0.02)$ & $(0.03)$ & $(0.02)$ \\
\hline
\end{tabular}

Notes: The marginal effects of total natural resources rents are calculated using the coefficients from Table 11, Columns $2,4,6,8,10$.

This conclusion, however, could be misleading. A re-examination of the regressions shows that this finding is not a general one: it may be driven by a small set of influential observations (which we formally identify using DFITS and DFBETA statistics). Indeed, when we re-estimate each of the above regressions, excluding such influential observations, the results suggest that the interaction effect between political institutions and resource rents looks more relevant than initially appeared (Tables 13 and 14).

Subject to the limitations of the cross-section approach discussed earlier, the above results suggest that the effect of natural resources is likely to work through institutions relating to impartiality of tax systems, while the evidence that they affect their effectiveness is weaker. In particular, the marginal effects indicate that a fiscal resource curse may affect the impartiality of tax systems, as well as basic infrastructure for tax collection (such as the taxpayer registration system), only in political systems with low levels of checks and balances on executive power. The curse disappears, or becomes a blessing, in economies that can successfully limit the power of the executive. Under such political conditions, the fiscal bargain between a ruler and citizens, at the heart of the construction of a fiscal state (Brautigam et al., 2008), may be facilitated. 
Table 13. Tests of possible channels of causation from resource rents to fiscal capacity - Excluding outliers

\begin{tabular}{|c|c|c|c|c|c|c|c|c|c|c|}
\hline DEPENDENT VARIABLES & $\begin{array}{c}\text { (1) } \\
\text { Transparency } \\
\text { of taxpayer } \\
\text { obligations } \\
\text { and liabilities }\end{array}$ & $\begin{array}{c}(2) \\
\text { Transparency } \\
\text { of taxpayer } \\
\text { obligations } \\
\text { and liabilities }\end{array}$ & $\begin{array}{c}\text { (3) } \\
\text { Tax appeals }\end{array}$ & $\begin{array}{c}\text { (4) } \\
\text { Tax } \\
\text { appeals }\end{array}$ & $\begin{array}{c}(5) \\
\text { Controls in } \\
\text { the } \\
\text { taxpayer } \\
\text { registration } \\
\text { system }\end{array}$ & $\begin{array}{l}(6) \\
\text { Controls in } \\
\text { the } \\
\text { taxpayer } \\
\text { registration } \\
\text { system }\end{array}$ & $\begin{array}{c}(7) \\
\text { Effectiveness } \\
\text { of penalties for } \\
\text { non- } \\
\text { compliance } \\
\text { with } \\
\text { registration and } \\
\text { tax declaration } \\
\end{array}$ & $\begin{array}{c}(8) \\
\text { Effectiveness } \\
\text { of penalties for } \\
\text { non- } \\
\text { compliance } \\
\text { with } \\
\text { registration and } \\
\text { tax declaration } \\
\end{array}$ & $\begin{array}{c}(9) \\
\text { Quality of } \\
\text { tax audit }\end{array}$ & $\begin{array}{c}\text { (10) } \\
\text { Quality of } \\
\text { tax audit }\end{array}$ \\
\hline Total natural resources rents & $\begin{array}{l}-0.0150 \\
(0.0101)\end{array}$ & $\begin{array}{c}-0.0606 * * \\
(0.0227)\end{array}$ & $\begin{array}{l}-0.00964 \\
(0.00910)\end{array}$ & $\begin{array}{c}-0.0439 * * * \\
(0.0133)\end{array}$ & $\begin{array}{c}-0.0144 * * \\
(0.00613)\end{array}$ & $\begin{array}{l}-0.0177 \\
(0.0138)\end{array}$ & $\begin{array}{l}-0.0120 \\
(0.0174)\end{array}$ & $\begin{array}{l}-0.0503^{*} \\
(0.0257)\end{array}$ & $\begin{array}{l}-0.00189 \\
(0.0127)\end{array}$ & $\begin{array}{l}0.00123 \\
(0.0221)\end{array}$ \\
\hline Executive constraints & $\begin{array}{c}0.0901 \\
(0.0893)\end{array}$ & $\begin{array}{c}0.000992 \\
(0.0983)\end{array}$ & $\begin{array}{l}0.260 * * * \\
(0.0834)\end{array}$ & $\begin{array}{l}0.188^{* *} \\
(0.0861)\end{array}$ & $\begin{array}{l}0.315^{* * *} \\
(0.0646)\end{array}$ & $\begin{array}{c}0.308^{* * *} \\
(0.0762)\end{array}$ & $\begin{array}{l}0.275^{* * *} * \\
(0.0868)\end{array}$ & $\begin{array}{c}0.190^{*} \\
(0.0952)\end{array}$ & $\begin{array}{c}0.113 \\
(0.0843)\end{array}$ & $\begin{array}{c}0.120 \\
(0.0947)\end{array}$ \\
\hline Tot.resources rents*Ex. constraints & & $\begin{array}{l}0.0207 * * \\
(0.00892)\end{array}$ & & $\begin{array}{c}0.0118 * * * \\
(0.00430)\end{array}$ & & $\begin{array}{c}0.00116 \\
(0.00444)\end{array}$ & & $\begin{array}{l}0.0135^{* *} \\
(0.00530)\end{array}$ & & $\begin{array}{c}-0.00111 \\
(0.00470)\end{array}$ \\
\hline Political stability & $\begin{array}{c}-0.00570 \\
(0.145)\end{array}$ & $\begin{array}{c}-0.0149 \\
(0.146)\end{array}$ & $\begin{array}{c}0.130 \\
(0.109)\end{array}$ & $\begin{array}{c}0.108 \\
(0.110)\end{array}$ & $\begin{array}{l}-0.0341 \\
(0.134)\end{array}$ & $\begin{array}{c}-0.0363 \\
(0.136)\end{array}$ & $\begin{array}{l}0.0966 \\
(0.152)\end{array}$ & $\begin{array}{l}0.0673 \\
(0.158)\end{array}$ & $\begin{array}{c}-0.318^{* *} \\
(0.129)\end{array}$ & $\begin{array}{c}-0.316^{* *} \\
(0.132)\end{array}$ \\
\hline Net ODA and aid per capita & $\begin{array}{l}0.000585 \\
(0.00148)\end{array}$ & $\begin{array}{c}0.000932 \\
(0.00153)\end{array}$ & $\begin{array}{c}-0.00258 * * * \\
(0.000910)\end{array}$ & $\begin{array}{l}-0.00218 * * \\
(0.000860)\end{array}$ & $\begin{array}{l}0.000119 \\
(0.00154)\end{array}$ & $\begin{array}{l}0.000159 \\
(0.00158)\end{array}$ & $\begin{array}{l}-1.62 \mathrm{e}-05 \\
(0.00160)\end{array}$ & $\begin{array}{l}0.000417 \\
(0.00157)\end{array}$ & $\begin{array}{l}0.000277 \\
(0.00209)\end{array}$ & $\begin{array}{l}0.000241 \\
(0.00214)\end{array}$ \\
\hline Population density & $\begin{array}{c}0.000393 \\
(0.000775)\end{array}$ & $\begin{array}{c}0.000690 \\
(0.000731)\end{array}$ & $\begin{array}{c}0.000136 \\
(0.000735)\end{array}$ & $\begin{array}{c}0.000152 \\
(0.000646)\end{array}$ & $\begin{array}{c}-0.000249 \\
(0.000453)\end{array}$ & $\begin{array}{l}-0.000247 \\
(0.000458)\end{array}$ & $\begin{array}{c}-1.48 \mathrm{e}-05 \\
(0.000625)\end{array}$ & $\begin{array}{c}1.37 \mathrm{e}-05 \\
(0.000556)\end{array}$ & $\begin{array}{c}0.000446 \\
(0.000593)\end{array}$ & $\begin{array}{c}0.000443 \\
(0.000594)\end{array}$ \\
\hline External conflict & $\begin{array}{c}0.301 * * \\
(0.130)\end{array}$ & $\begin{array}{c}0.319 * * \\
(0.130)\end{array}$ & $\begin{array}{c}0.170 \\
(0.121)\end{array}$ & $\begin{array}{c}0.181 \\
(0.122)\end{array}$ & $\begin{array}{l}0.0852 \\
(0.138)\end{array}$ & $\begin{array}{l}0.0863 \\
(0.140)\end{array}$ & $\begin{array}{c}0.177 \\
(0.112)\end{array}$ & $\begin{array}{l}0.192 * \\
(0.111)\end{array}$ & $\begin{array}{c}0.170 \\
(0.127)\end{array}$ & $\begin{array}{c}0.169 \\
(0.128)\end{array}$ \\
\hline Civil war & $\begin{array}{l}-0.0290 \\
(0.230)\end{array}$ & $\begin{array}{l}-0.0470 \\
(0.227)\end{array}$ & $\begin{array}{l}0.0391 \\
(0.212)\end{array}$ & $\begin{array}{l}0.0466 \\
(0.218)\end{array}$ & $\begin{array}{c}0.133 \\
(0.261)\end{array}$ & $\begin{array}{c}0.134 \\
(0.263)\end{array}$ & $\begin{array}{l}-0.203 \\
(0.208)\end{array}$ & $\begin{array}{l}-0.202 \\
(0.206)\end{array}$ & $\begin{array}{c}0.174 \\
(0.194)\end{array}$ & $\begin{array}{c}0.174 \\
(0.197)\end{array}$ \\
\hline Length of statehood & $\begin{array}{c}0.00545 \\
(0.00543)\end{array}$ & $\begin{array}{c}0.00454 \\
(0.00547)\end{array}$ & $\begin{array}{c}0.00461 \\
(0.00409)\end{array}$ & $\begin{array}{c}0.00556 \\
(0.00395)\end{array}$ & $\begin{array}{l}0.000624 \\
(0.00272)\end{array}$ & $\begin{array}{l}0.000718 \\
(0.00274)\end{array}$ & $\begin{array}{c}0.00346 \\
(0.00457)\end{array}$ & $\begin{array}{c}0.00491 \\
(0.00428)\end{array}$ & $\begin{array}{c}0.00577 \\
(0.00366)\end{array}$ & $\begin{array}{c}0.00566 \\
(0.00375)\end{array}$ \\
\hline Constant & $\begin{array}{c}0.756 \\
(0.822)\end{array}$ & $\begin{array}{l}1.057 \\
(0.879)\end{array}$ & $\begin{array}{l}-0.402 \\
(0.735)\end{array}$ & $\begin{array}{l}-0.150 \\
(0.748)\end{array}$ & $\begin{array}{c}0.460 \\
(0.808)\end{array}$ & $\begin{array}{c}0.485 \\
(0.831)\end{array}$ & $\begin{array}{c}0.296 \\
(0.929)\end{array}$ & $\begin{array}{l}0.576 \\
(0.984)\end{array}$ & $\begin{array}{l}1.453 \\
(0.882)\end{array}$ & $\begin{array}{c}1.430 \\
(0.910)\end{array}$ \\
\hline Observations & 59 & 59 & 60 & 60 & 60 & 60 & 60 & 60 & 61 & 61 \\
\hline $\begin{array}{l}\text { Adjusted R-squared } \\
\text { Joint(p) }\end{array}$ & 0.209 & $\begin{array}{c}0.237 \\
0.0324\end{array}$ & 0.258 & $\begin{array}{c}0.295 \\
0.00699\end{array}$ & 0.309 & $\begin{array}{c}0.294 \\
0.0616\end{array}$ & 0.149 & $\begin{array}{c}0.182 \\
0.0477\end{array}$ & 0.343 & $\begin{array}{l}0.330 \\
0.937\end{array}$ \\
\hline Excluding: & \multicolumn{2}{|c|}{$\begin{array}{c}\text { Trinidad and Tobago, } \\
\text { Moldova }\end{array}$} & \multicolumn{2}{|c|}{ Liberia } & \multicolumn{2}{|c|}{ Liberia } & \multicolumn{2}{|c|}{ Jamaica, Liberia } & \multicolumn{2}{|c|}{ Liberia } \\
\hline
\end{tabular}


Table 14. Effects of resource intensity on fiscal capacity at different levels of executive

\begin{tabular}{|c|c|c|c|c|c|}
\hline & \multicolumn{3}{|c|}{ constraints - no outliers } & \multirow[b]{2}{*}{$\begin{array}{c}\text { Effectiveness of } \\
\text { penalties for } \\
\text { non-compliance } \\
\text { with registration } \\
\text { and tax } \\
\text { declaration }\end{array}$} & \multirow[b]{2}{*}{$\begin{array}{c}\text { Quality of tax } \\
\text { audit }\end{array}$} \\
\hline \multirow[b]{2}{*}{$\begin{array}{l}\text { Executive } \\
\text { constraints }\end{array}$} & $\begin{array}{c}\text { Transparency of } \\
\text { taxpayer } \\
\text { obligations and } \\
\text { liabilities }\end{array}$ & $\begin{array}{l}\text { Tax appeals } \\
\text { mechanisms }\end{array}$ & $\begin{array}{l}\text { Controls in the } \\
\text { taxpayer } \\
\text { registration } \\
\text { system }\end{array}$ & & \\
\hline & $\mathrm{b} / \mathrm{se}$ & $\mathrm{b} / \mathrm{se}$ & $\mathrm{b} / \mathrm{se}$ & $\mathrm{b} / \mathrm{se}$ & $\mathrm{b} / \mathrm{se}$ \\
\hline \multirow{2}{*}{1} & $-0.040 * * *$ & $-0.032 * * *$ & $-0.017 *$ & $-0.037 *$ & 0.000 \\
\hline & $(0.01)$ & $(0.01)$ & $(0.01)$ & $(0.02)$ & $(0.02)$ \\
\hline \multirow{2}{*}{2} & $-0.019 * *$ & $-0.020 * * *$ & $-0.015^{* *}$ & -0.023 & -0.001 \\
\hline & $(0.01)$ & $(0.01)$ & $(0.01)$ & $(0.02)$ & $(0.01)$ \\
\hline \multirow{2}{*}{3} & 0.001 & -0.009 & $-0.014 * *$ & -0.010 & -0.002 \\
\hline & $(0.01)$ & $(0.01)$ & $(0.01)$ & $(0.02)$ & $(0.01)$ \\
\hline \multirow{2}{*}{4} & 0.022 & 0.003 & -0.013 & 0.004 & -0.003 \\
\hline & $(0.02)$ & $(0.01)$ & $(0.01)$ & $(0.02)$ & $(0.01)$ \\
\hline \multirow{2}{*}{5} & $0.043^{*}$ & 0.015 & -0.012 & 0.017 & -0.004 \\
\hline & $(0.02)$ & $(0.01)$ & $(0.01)$ & $(0.02)$ & $(0.01)$ \\
\hline \multirow{2}{*}{6} & $0.063^{*}$ & $0.027 *$ & -0.011 & 0.031 & -0.005 \\
\hline & $(0.03)$ & $(0.02)$ & $(0.02)$ & $(0.02)$ & $(0.01)$ \\
\hline \multirow{2}{*}{7} & $0.084 * *$ & $0.039 * *$ & -0.010 & $0.044^{*}$ & -0.007 \\
\hline & $(0.04)$ & $(0.02)$ & $(0.02)$ & $(0.02)$ & $(0.02)$ \\
\hline
\end{tabular}

Notes: The marginal effects of total natural resources rents are calculated using the coefficients from Table 13, Columns $2,4,6,8,10$.

\section{Conclusions}

This paper investigates how natural resource rents affect the incentives for investing in fiscal capacity and the role of political institutions in this process. Building on previous studies demonstrating that institutions can create the conditions to offset (or even reverse) the resource curse, we posit that the negative effect of resource rents on the ability of states to raise revenues depends on whether political institutions effectively limit executive power, as they give incumbents little discretion over the use of resource rents. Using panel data covering the period 1981-2011 for 98 developing countries, we find that resource rents are negatively associated with fiscal capacity, measured as the share of non-resource taxes on income, profits and capital gains in non-resource total taxes. However, countries with a high level of executive constraints are able to neutralise (or even reverse) this effect. Further analysis, based on cross-section estimates and a recent dataset on the characteristics of tax systems in developing economies, shows that the effect of natural resources is likely to work mainly through institutions that make the tax system accountable to and transparent for citizens.

Our results are in line with the recent literature arguing that resource abundance does not lead to worse development outcomes, if a country has the 'right' institutions (e.g., Wiens, 2014; Melhum et al., 2006), extending this view to the case of fiscal capacity. Perhaps they 
are even more relevant to the literature on the determinants of state capacity, where it has recently been argued that political institutions constraining the power of the executive foster fiscal (and legal) capacity by creating a situation of 'common interest' (Besley and Persson, 2011). We add to this claim that another channel through which such political institutions may foster state capacity is by averting any deleterious effect of resource rents. Moreover, our results echo recent case studies showing that, from a historical perspective, becoming a resource-rich economy has concurrently promoted state building, contingent on the social roots of political coalitions that rule during the boom (Saylor, 2014) or on having a stable democracy (Dargent et al., 2017). Finally, in policy terms, our findings indicate that, in polities providing strong checks and balances on the executive power, it is possible to develop both fiscal capacity and the natural resources sector, without any trade-off. Whether a fiscal resource curse exists or not is a question of what type of political institutions countries adopted before they became resource-rich. 


\section{References}

Acemoglu, D., Johnson, S., Robinson, J. A. and Yared, P. (2005). 'From education to democracy?' American Economic Review, 95(2): 44-49.

Alexeev, M. and Conrad, R. (2009). 'The elusive curse of oil'. The Review of Economics and Statistics, 91(3): 586-598.

Andersen, J. J. and Aslaksen, S. (2008). 'Constitutions and the resource curse'. Journal of Development Economics, 87(2): 227-246, October.

Besley, T. and Persson, T. (2014). 'Why do developing countries tax so little?' Journal of Economic Perspectives, 28(4): 99-120.

Besley, T. and Persson, T. (2011). Pillars of Prosperity: The Political Economics of Development Clusters. Princeton, NJ: Princeton University Press.

Bhattacharyya, S. and Hodler, R. (2010). 'Natural resources, democracy and corruption'. European Economic Review, 54(4): 608-621.

Bhattacharyya, S. and Hodler, R. (2014). 'Do natural resource revenues hinder financial development? The role of political institutions'. World Development, 57: 101-113.

Bjorvatn, K. and Naghavi. A. (2011). 'Rent seeking and regime stability in rentier states'. European Journal of Political Economy, 27(4): 740-748.

Bodea, C., Higashijima, M. and Singh, R. J. (2016). 'Oil and civil conflict: Can public spending have a mitigation effect?' World Development, 78: 1-12.

Boschini, A. D., Pettersson, J. and Roine, J. (2007). 'Resource curse or not: A question of appropriability'. The Scandinavian Journal of Economics, 109(3): 593-617.

Bornhorst, F., Gupta, S. and Thornton, J. (2009). 'Natural resource endowments and the domestic revenue effort'. European Journal of Political Economy, 25(4): 439-446.

Brautigam, D., Fjeldstad, O. H and, Moore, M. (2008). Taxation and State-building in Developing Countries: Capacity and Consent. Cambridge: Cambridge University Press.

Brunnschweiler, C. N. (2008). 'Cursing the blessings? Natural resource abundance, institutions, and economic growth'. World Development, 36(3): 399-419.

Brunnschweiler, C. N. and Bulte, E. H. (2008). 'The resource curse revisited and revised: A tale of paradoxes and red herrings'. Journal of Environmental Economics and Management, 55(3): 248-264.

Carmignani, F. (2013). 'Development outcomes, resource abundance, and the transmission through inequality'. Resource and Energy Economics, 35: 412-428 
Caselli, F. and Cunningham, T. (2009). 'Leader behaviour and the natural resource curse'. Oxford Economic Papers, 61(4): 628-650.

Caselli, F. and Michaels, G. (2013). 'Do oil windfalls improve living standards? Evidence from Brazil'. American Economic Journal: Applied Economics, 5(1): 208-238.

Caselli, F. and Tesei, A. (2016). 'Resource windfalls, political regimes, and political stability'. Review of Economics and Statistics, 98(3): 573-590.

Centeno, M. A., Kohli, A. and Yashar, D. J. (2017). 'Unpacking states in the developing world: Capacity, performance, and politics', in M. A. Centeno, A. Kohli and D. J. Yashar (eds.), States in the Developing World. Cambridge: Cambridge University Press.

Charron, N., Dahlström, C. and Lapuente, V. (2012). 'No law without a state', Journal of Comparative Economics, 40(2): 176-193.

Collier, P. and Hoeffler, A. (2004). 'Greed and grievance in civil war'. Oxford Economic Papers, 56(4): 563-595.

Cotet, A. M. and Tsui, K. K. (2013). 'Oil and conflict: What does the cross country evidence really show?'. American Economic Journal: Macroeconomics, 5(1): 49-80.

Crivelli, E. and Gupta, S. (2014). 'Resource blessing, revenue curse? Domestic revenue effort in resource-rich countries'. European Journal of Political Economy, 35: 88-101.

Dargent E., Feldmann, A. E. and Luna, J. P. (2017). 'Greater state capacity, lesser stateness: Lessons from the Peruvian commodity boom'. Politics \& Society, 45(1): 3-34.

Ebeke, C., Omgba, L. D. and Laajaj, R. (2015). 'Oil, governance and the (mis) allocation of talent in developing countries'. Journal of Development Economics, 114: 126-141.

Edwards, R. B. (2016). 'Mining away the Preston curve'. World Development, 78: 22-36.

Ehrhart, H. (2012). 'Assessing the relationship between democracy and domestic taxes in developing countries'. Economics Bulletin, 32(1): 551-566.

El Anshasy, A. A. and Katsaiti, M. S. (2013). 'Natural resources and fiscal performance: Does good governance matter?' Journal of Macroeconomics, 37: 285-298.

Fum R. M. and Hodler, R. (2010). 'Natural resources and income inequality: The role of ethnic divisions'. Economics Letters, 107(3): 360-363.

Gylfason, T. (2001). 'Natural resources, education, and economic development'. European Economic Review, 45: 847-859.

Goderis, B. and Malone, S. W. (2011). 'Natural resource booms and inequality: Theory and evidence'. Scandinavian Journal of Economics, 113(2): 388-417. 
Haber, S. and Menaldo, V. (2011). 'Do natural resources fuel authoritarianism? A reappraisal of the resource curse'. American Political Science Review, 105(01): 1-26.

Herbst, J. (2000). States and Power in Africa: Comparative Lessons in Authority and Control. Princeton, NJ: Princeton University Press.

ICTD - International Centre for Tax and Development (2015). 'Government Revenue Dataset 2015'. Available at http://www.ictd.ac/en/node/436/ (accessed 1 March 2016).

Isham, J., Woolcock, M., Pritchett, L. and Busby, G. (2005). 'The varieties of resource experience: Natural resource export structures and the political economy of economic growth'. The World Bank Economic Review, 19(2): 141-174.

James, A. (2015). 'US state fiscal policy and natural resources'. American Economic Journal: Economic Policy, 7(3): 238-257.

Jensen, A. D. (2011). 'State-building in resource-rich economies'. Atlantic Economic Journal, 39: 171-193.

Levi, M. (1988). Of Rule and Revenue, Berkeley, CA: University of California Press.

Lieberman, E. S. (2002), 'Taxation data as indicators of state-society relations: Possibilities and pitfalls in cross-national research'. Studies in Comparative International Development, 36(4): 89-115.

Karl, T. L. (2004). 'Oil-led development: Social, political, and economic consequences'. Encyclopaedia of Energy, 4: 661-672. Elsevier.

Knack, S. (2009). 'Sovereign rents and quality of tax policy and administration'. Journal of Comparative Economics, 37(3): 359-371.

Klomp, J. and de Haan, J. (2016). 'Election cycles in natural resource rents: Empirical evidence'. Journal of Development Economics, 121: 79-93.

Kurtz, M. J. and Brooks, S. M. (2011). 'Conditioning the "resource curse": Globalization, human capital, and growth in oil-rich nations'. Comparative Political Studies, 44(6): 747770 .

Marshall, M. G., Gurr, T. R. and Jaggers, K. (2014). 'Polity IV Project: Political regime characteristics and transitions, 1800-2013'. Available at: http://www.systemicpeace.org/polity/polity4.htm (accessed 12 February 2018).

Mehlum, H., Moene, K. and Torvik, R. (2006). 'Institutions and the resource curse'. The Economic Journal, 116(508): 1-20.

Morrison, K. M. (2010). 'What can we learn about the "resource curse" from foreign aid?' The World Bank Research Observer, 27: 52-73. 
Morrison, K. M. (2009). 'Oil, nontax revenue, and the redistributional foundations of regime stability'. International Organization, 63(01): 107-138.

Morrissey, O., Von Haldenwang, C., Von Schiller, A., Ivanyna, M. and Bordon, I. (2016). 'Tax revenue performance and vulnerability in developing countries'. The Journal of Development Studies, 52(12): 1689-1703.

Norman, C. S. (2009). 'Rule of law and the resource curse: Abundance versus intensity'. Environmental and Resource Economics, 43: 183-207.

Omgba, L. D. (2015). 'Why do some oil-producing countries succeed in democracy while others fail?'. World Development, 76: 180-189.

Osafo-Kwaako, P. and Robinson, J. A. (2013). 'Political centralization in pre-colonial Africa'. Journal of Comparative Economics, 41(1): 6-21.

Palmer, G., D'Orazio, V., Kenwick, M. and Lane, M. (2015). 'The MID4 data set: Procedures, coding rules, and description'. Conflict Management and Peace Science, 32(2): 222-24.

Pineda, J. and Rodríguez, F. (2010). 'Curse or blessing? Natural resources and human development'. Human Development Research Paper 2010/04.

Prichard, W., Cobham, A. and Goodall, A. (2014). 'The ICTD government revenue dataset'. ICTD Working Paper 34.

Robinson, J. A., Torvik, R. and Verdier, T. (2006). 'Political foundations of the resource curse'. Journal of Development Economics, 79(2): 447-468, April.

Rodriguez, F. and Sachs, J. D. (1999). 'Why do resource-abundant economies grow more slowly?' Journal of Economic Growth, 4(3): 277-303.

Ross, M. L. (2001). 'Does oil hinder democracy?' World Politics, 53(3): 325-361.

Sachs, J. D. and Warner, A.M. (1999). 'The big push, natural resource booms and growth'. Journal of Development Economics, 59(1): 43-76.

Sachs, J. D. and Warner, A. M. (2001). 'The curse of natural resources'. European Economic Review, 45: 827-838.

Savoia, A. and Sen, K. (2015). 'Measurement, evolution, determinants and consequences of state capacity: A review of recent research'. Journal of Economic Surveys, 29(3): 441458.

Saylor, R. (2014). State Building in Boom Times: Commodities and Coalitions in Latin America and Africa, Oxford: Oxford University Press.

Stijns, J. (2006). 'Natural resource abundance and human capital accumulation'. World Development, 34(6):1060-1083. 
Tornell, A. and Lane, P.R. (1999). 'The voracity effect'. American Economic Review, 89(1): 22-46.

Torvik, R. (2002). 'Natural resources, rent seeking and welfare'. Journal of Development Economics, 67(2): 455-470.

UCDP/PRIO (2016). Armed Conflict Dataset. Available at https://www.prio.org/Data/ArmedConflict/UCDP-PRIO/ (accessed 12 February 2018).

Vahabi M. (2016). The Political Economy of Predation: Manhunting and the Economics of Escape. New York: Cambridge University Press.

Van der Ploeg, F. (2011). 'Natural resources: Curse or blessing?' Journal of Economic Literature, 49(2): 366-420.

Wiens, D. (2014), 'Natural resources and institutional development'. Journal of Theoretical Politics, 26(2): 197-221.

World Bank (2011). The Changing Wealth of Nations: Measuring Sustainable Development in the New Millennium. Washington, DC: World Bank.

World Bank (2016). World Development Indicators. Washington, DC: World Bank. Available at http://data.worldbank.org/data-catalog/world-development-indicators (accessed 12 February 2018). 


\section{Appendix}

Table 1A. Variables and sources

\begin{tabular}{|c|c|c|}
\hline Variable & Description & Source \\
\hline $\begin{array}{l}\text { Non-resource tax } \\
\text { excluding social } \\
\text { contributions }\end{array}$ & $\begin{array}{l}\text { Non-resource component of total tax revenue } \\
\text { excluding social contributions and natural } \\
\text { resource revenue. }\end{array}$ & GRD dataset, ICTD (2015) \\
\hline Fiscal capacity & $\begin{array}{l}\text { Non-resource component of taxes on income, } \\
\text { profits, and capital gains as a percentage of non- } \\
\text { resource component of total tax revenue } \\
\text { excluding social contributions and natural } \\
\text { resource revenue. }\end{array}$ & $\begin{array}{l}\text { Own elaboration based on data from } \\
\text { GRD dataset, ICTD (2015) }\end{array}$ \\
\hline Executive constraints & $\begin{array}{l}\text { Institutionalised constraints on the decision- } \\
\text { making power of chief executives ranging from } 1 \\
\text { (unlimited authority) to } 7 \text { (limited authority). } \\
\text { Values outside }[1 ; 7] \text { are treated as missing. }\end{array}$ & Polity IV Project (Marshall et al. 2014) \\
\hline $\begin{array}{l}\text { Total natural resources } \\
\text { rents }\end{array}$ & $\begin{array}{l}\text { Total natural resources rents ( } \% \text { of GDP). It is } \\
\text { the sum of oil rents, natural gas rents, mineral } \\
\text { rents, and forest rents. }\end{array}$ & World Bank (2016) \\
\hline Forest rents & Forest rents (\% of GDP). & World Bank (2016) \\
\hline Oil rents & Oil rents ( $\%$ of GDP). & World Bank (2016) \\
\hline Gas rents & Gas rents ( $\%$ of GDP). & World Bank (2016) \\
\hline Mineral rents & Mineral rents ( $\%$ of GDP). & World Bank (2016) \\
\hline Political stability & $\begin{array}{l}\text { Sum of xropen (openness of executive } \\
\text { recruitment) and xrcomp (competitiveness of } \\
\text { executive recruitment) variables in the Polity IV } \\
\text { dataset ranging from } 2 \text { (instable) to } 7 \text { (stable). }\end{array}$ & Polity IV Project (Marshall et al. 2014) \\
\hline External debt & External debt stocks (\% of GNI). & World Bank (2016) \\
\hline Trade & Trade ( $\%$ of GDP). & World Bank (2016) \\
\hline $\begin{array}{l}\text { Net ODA and aid per } \\
\text { capita }\end{array}$ & $\begin{array}{l}\text { Net official development assistance and official } \\
\text { aid received (constant } 2013 \text { US } \$ \text { ) per capita. }\end{array}$ & $\begin{array}{l}\text { Own elaboration based on data from } \\
\text { World Bank (2016) }\end{array}$ \\
\hline
\end{tabular}


Population density

External conflict

Civil war
Population density (people per sq. $\mathrm{km}$ of land

area).

Hostility level of interstate dispute ranging from 0

(no dispute) to 5 (war)

Intensity level of internal and internationalised UCDP/PRIO (2016), Armed Conflict

internal armed conflict ranging from 0 (no Dataset

conflict) to 2 (more than 1000 battle-related
World Bank (2016)

Palmer et al. (2015)

deaths). 
Table 2A. Countries

\begin{tabular}{|c|c|c|c|}
\hline \multicolumn{4}{|c|}{ (a) Panel } \\
\hline Albania & Dominican Republic & Lebanon & Peru \\
\hline Algeria & Ecuador & Lesotho & Philippines \\
\hline Angola & Egypt, Arab Rep. & Liberia & Romania \\
\hline Armenia & El Salvador & Macedonia, FYR & Senegal \\
\hline Azerbaijan & Eritrea & Madagascar & Sierra Leone \\
\hline Bangladesh & Fiji & Malawi & Solomon Islands \\
\hline Belarus & Gabon & Malaysia & South Africa \\
\hline Benin & Gambia, The & Mali & Sri Lanka \\
\hline Bhutan & Georgia & Mauritania & Swaziland \\
\hline Bolivia & Guatemala & Mauritius & Syrian Arab Republic \\
\hline Botswana & Guinea-Bissau & Mexico & Tajikistan \\
\hline Brazil & Guyana & Moldova & Tanzania \\
\hline Bulgaria & Haiti & Mongolia & Thailand \\
\hline Burundi & Honduras & Morocco & Togo \\
\hline Cabo Verde & India & Mozambique & Tunisia \\
\hline Cameroon & Indonesia & Nepal & Turkey \\
\hline Central African Republic & Iran, Islamic Rep. & Nicaragua & Uganda \\
\hline China & Jamaica & Niger & Ukraine \\
\hline Comoros & Jordan & Nigeria & Uzbekistan \\
\hline Congo, Rep. & Kazakhstan & Pakistan & Vietnam \\
\hline Costa Rica & Kenya & Panama & Zambia \\
\hline Cote d'Ivoire & Kyrgyz Republic & Papua New Guinea & Zimbabwe \\
\hline Djibouti & Lao PDR & Paraguay & \\
\hline \multicolumn{4}{|c|}{ (b) Cross section } \\
\hline Afghanistan & Dominican Republic & Lao PDR & Peru \\
\hline Albania & El Salvador & Lesotho & Philippines \\
\hline Armenia & Ethiopia & Liberia & Senegal \\
\hline
\end{tabular}




\begin{tabular}{llll} 
Bangladesh & Gabon & Madagascar & Sierra Leone \\
Belarus & Georgia & Malawi & South Africa \\
Benin & Ghana & Mali & Swaziland \\
Bolivia & Guatemala & Mauritania & Tajikistan \\
Botswana & Haiti & Mauritius & Thailand \\
Brazil & Honduras & Moldova & Trinidad and Tobago \\
Cabo Verde & India & Morocco & Tunisia \\
Cambodia & Indonesia & Mozambique & Uganda \\
Central African Republic & Jamaica & Nepal & Ukraine \\
Colombia & Jordan & Niger & Vietnam \\
Congo, Rep. & Kenya & Pakistan & Yemen, Rep. \\
Costa Rica & Kyrgyz Republic & Paraguay & Zambia \\
Cote d'lvoire & & & \\
\hline
\end{tabular}


Figure 1A. Relationship between non resource-tax and natural resources rents
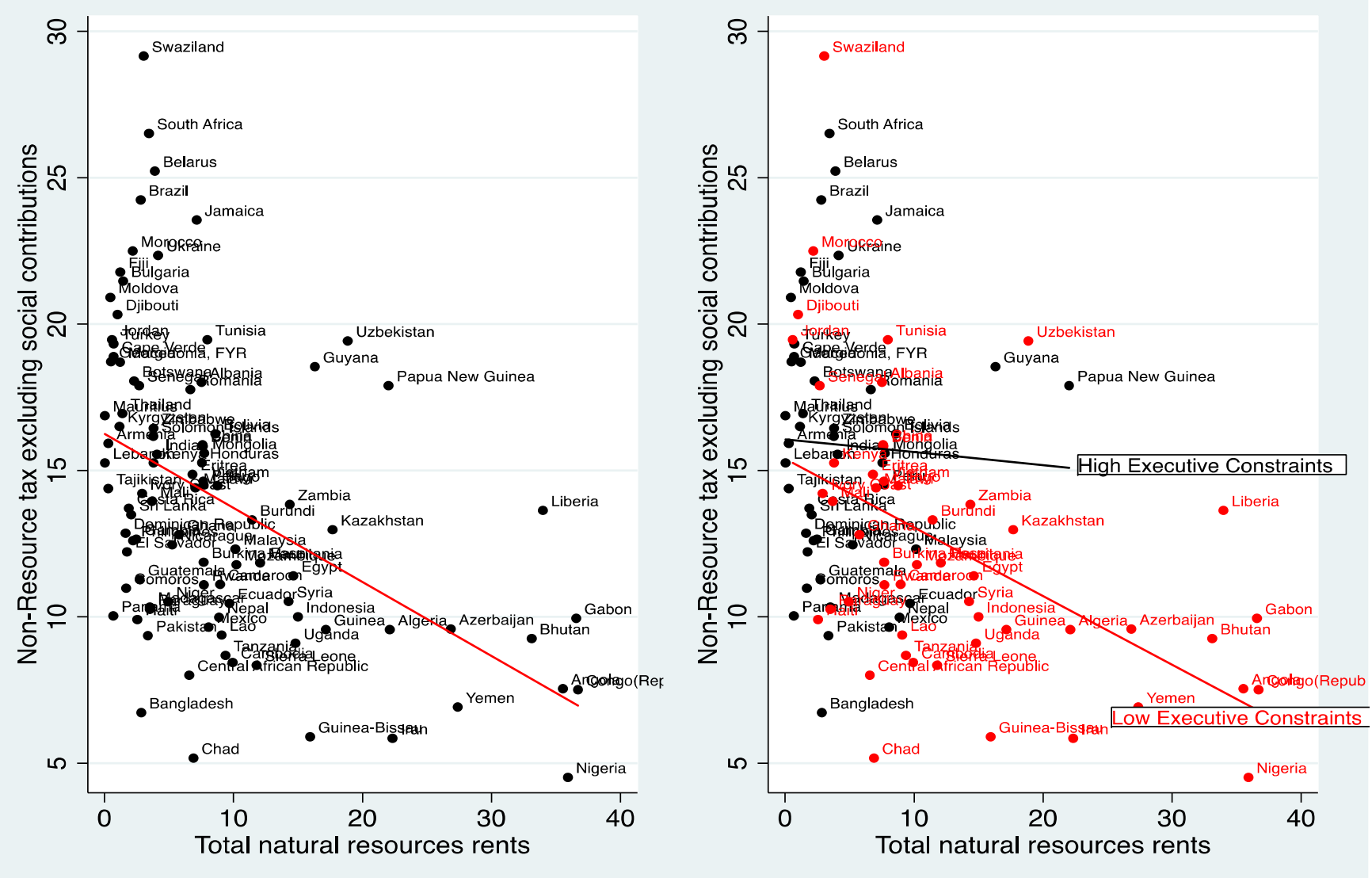
Figure 2A. Marginal effects of total natural resources rents at different levels of executive constraints

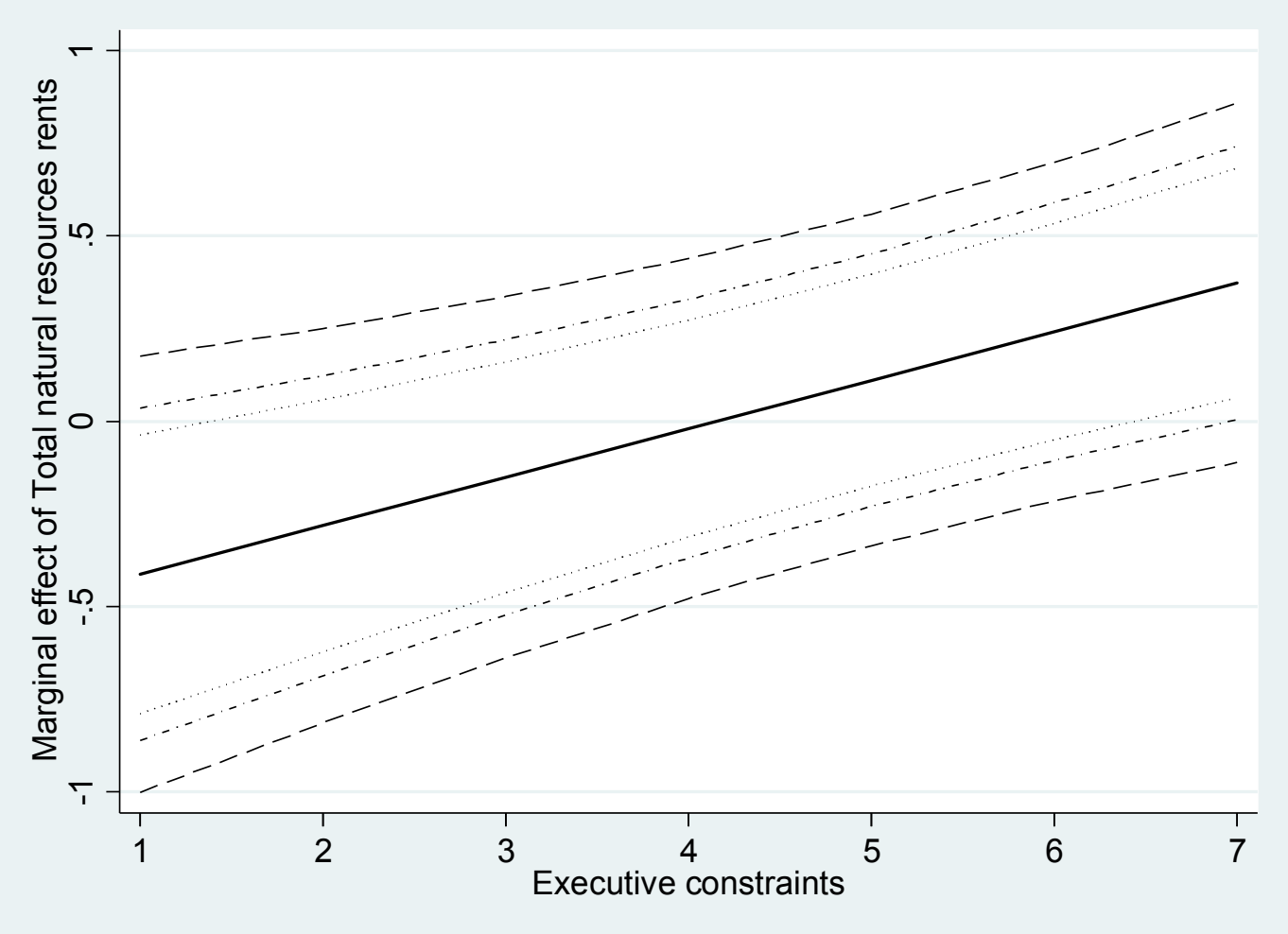

Figure 3A. Marginal effects of forest rents at different levels of executive constraints

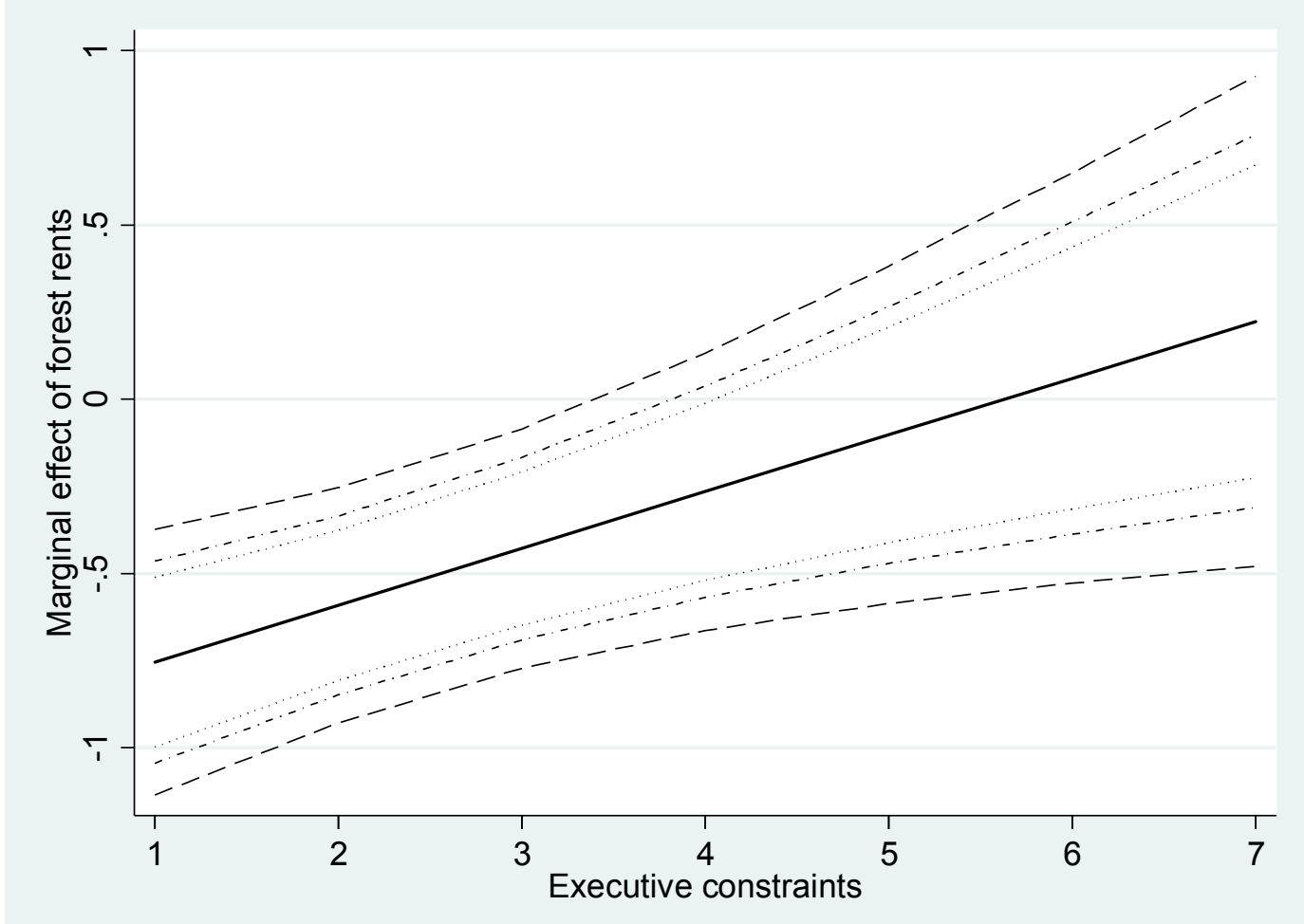


Figure 4A. Marginal effects of oil rents at different levels of executive constraints

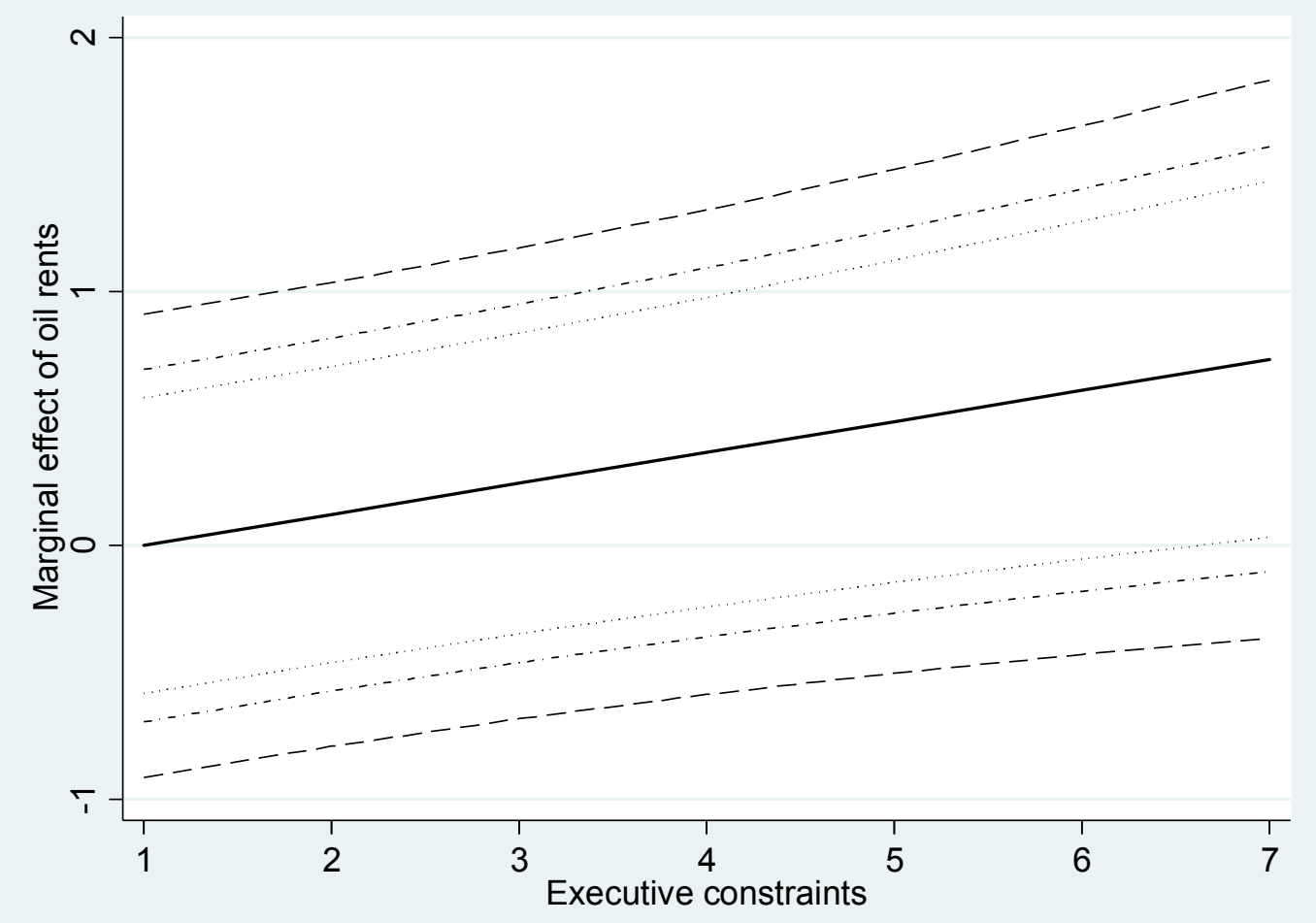

Figure 5A. Marginal effects of gas rents at different levels of executive constraints

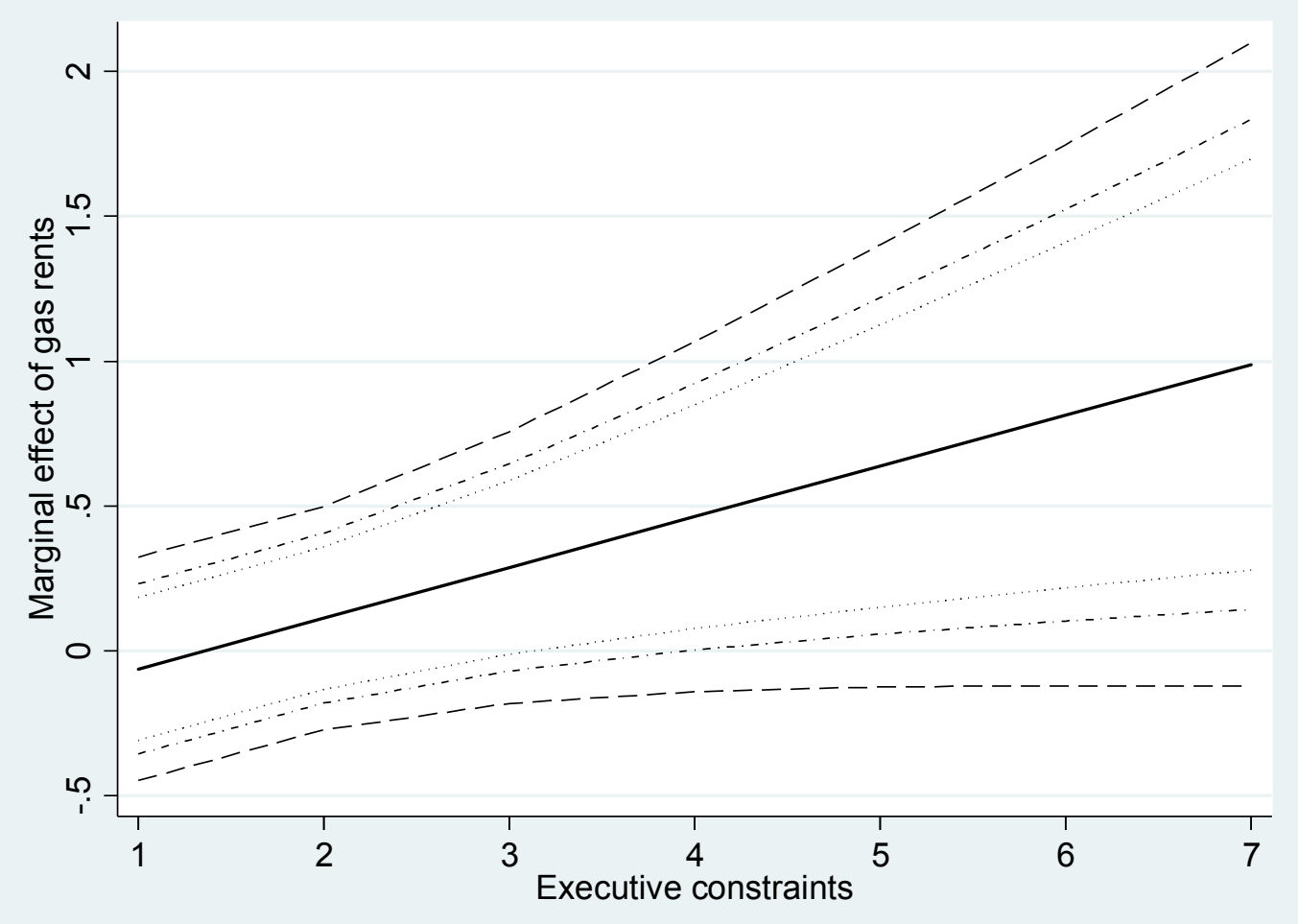


Figure 6A. Marginal effects of mineral rents at different levels of executive constraints

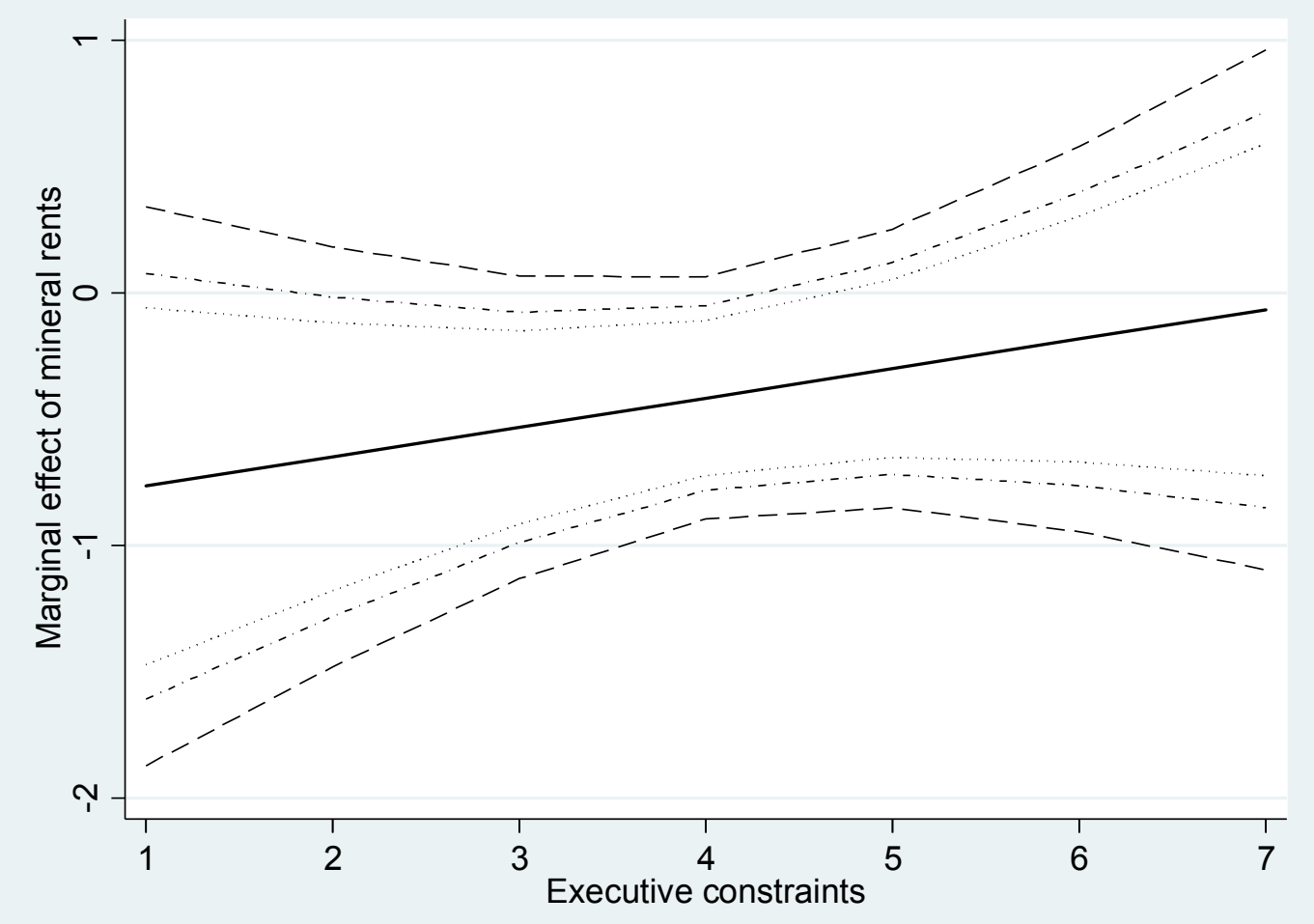




\section{esid}

\section{The Effective States and Inclusive Development Research Centre}

The Effective States and Inclusive Development Research Centre (ESID) aims to improve the use of governance research evidence in decision-making. Our key focus is on the role of state effectiveness and elite commitment in achieving inclusive development and social justice.

ESID is a partnership of highly reputed research and policy institutes based in Africa, Asia, Europe and North America. The lead institution is the University of Manchester.

The other institutional partners are:

- $\quad$ BRAC Institute of Governance and Development, BRAC University, Dhaka

- $\quad$ Center for Democratic Development, Accra

- $\quad$ Center for International Development, Harvard University, Boston

- Department of Political and Administrative Studies, University of Malawi, Zomba

- $\quad$ Graduate School of Development, Policy \& Practice, Cape Town University

- Institute for Economic Growth, Delhi

In addition to its institutional partners, ESID has established a network of leading research collaborators and policy/uptake experts. 